\title{
Climate change and mountain water resources: overview and recommendations for research, management and policy
}

\author{
D. Viviroli ${ }^{1,2}$, D. R. Archer ${ }^{3,4}$, W. Buytaert ${ }^{5}$, H. J. Fowler ${ }^{4}$, G. B. Greenwood ${ }^{6}$, A. F. Hamlet ${ }^{7}$, Y. Huang ${ }^{8}$, \\ G. Koboltschnig ${ }^{9,10}$, M. I. Litaor ${ }^{11}$, J. I. López-Moreno ${ }^{12}$, S. Lorentz ${ }^{13}$, B. Schädler ${ }^{1,2}$, H. Schreier $^{14}$, K. Schwaiger $^{15}$, \\ M. Vuille ${ }^{16}$, and R. Woods ${ }^{17}$ \\ ${ }^{1}$ Institute of Geography, University of Bern, Switzerland \\ ${ }^{2}$ Oeschger Centre for Climate Change Research, University of Bern, Switzerland \\ ${ }^{3}$ JBA Consulting, Skipton, North Yorkshire, UK \\ ${ }^{4}$ School of Civil Engineering and Geosciences, Newcastle University, UK \\ ${ }^{5}$ Imperial College, London, UK \\ ${ }^{6}$ Mountain Research Initiative, University of Bern, Switzerland \\ ${ }^{7}$ Department of Civil and Environmental Engineering and Center for Science in the Earth System Climate Impacts Group, \\ University of Washington, Seattle, WA, USA \\ ${ }^{8}$ Bureau of Hydrology, Changjiang Water Resources Commission, Wuhan, Hubei, China \\ ${ }^{9}$ International Research Society INTERPRAEVENT, Klagenfurt, Austria \\ ${ }^{10}$ Department for Water Management, Provincial Government of Carinthia, Klagenfurt, Austria \\ ${ }^{11}$ Department of Environmental Sciences, Tel-Hai Academic College, Israel \\ ${ }^{12}$ Pyrenean Institute of Ecology, Spanish Research Council, CSIC, Zaragoza, Spain \\ ${ }^{13}$ School of Bioresources Engineering \& Environmental Hydrology, University of KwaZulu-Natal, Pietermaritzburg, \\ South Africa \\ ${ }^{14}$ Institute for Resources, Environment and Sustainability, University of British Columbia, Canada \\ ${ }^{15}$ Federal Ministry of Agriculture, Forestry, Environment and Water Management, Vienna, Austria \\ ${ }^{16}$ Department of Atmospheric and Environmental Sciences, University at Albany, NY, USA \\ ${ }^{17}$ National Institute of Water and Atmospheric Research, Christchurch, New Zealand
}

Received: 27 April 2010 - Published in Hydrol. Earth Syst. Sci. Discuss.: 7 May 2010

Revised: 21 January 2011 - Accepted: 28 January 2011 - Published: 4 February 2011

\begin{abstract}
Mountains are essential sources of freshwater for our world, but their role in global water resources could well be significantly altered by climate change. How well do we understand these potential changes today, and what are implications for water resources management, climate change adaptation, and evolving water policy? To answer above questions, we have examined 11 case study regions with the goal of providing a global overview, identifying research gaps and formulating recommendations for research, management and policy.

After setting the scene regarding water stress, water management capacity and scientific capacity in our case study regions, we examine the state of knowledge in water resources from a highland-lowland viewpoint, focusing on mountain
\end{abstract}

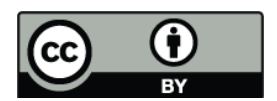

Correspondence to: D. Viviroli (viviroli@giub.unibe.ch) areas on the one hand and the adjacent lowland areas on the other hand. Based on this review, research priorities are identified, including precipitation, snow water equivalent, soil parameters, evapotranspiration and sublimation, groundwater as well as enhanced warming and feedback mechanisms. In addition, the importance of environmental monitoring at high altitudes is highlighted. We then make recommendations how advancements in the management of mountain water resources under climate change could be achieved in the fields of research, water resources management and policy as well as through better interaction between these fields.

We conclude that effective management of mountain water resources urgently requires more detailed regional studies and more reliable scenario projections, and that research on mountain water resources must become more integrative by linking relevant disciplines. In addition, the knowledge exchange between managers and researchers must be improved and oriented towards long-term continuous interaction.

Published by Copernicus Publications on behalf of the European Geosciences Union. 


\section{Introduction}

On a global scale, mountains contribute disproportionately high runoff, provide a favourable temporal redistribution of winter precipitation to spring and summer runoff and reduce the variability of flows in the adjacent lowlands (Viviroli et al., 2003; Viviroli and Weingartner, 2004). These mountain water resources are indispensable for irrigation, municipal and industrial water supply, hydropower production and environmental services provided by instream flow in rivers. The vital role of mountains and their relatively high sensitivity to projected warming and precipitation change can be deduced from several recent benchmark reports such as the Intergovernmental Panel on Climate Change Fourth Assessment Report (IPCC AR4) (Solomon et al., 2007; Parry et al., 2007) and the associated Technical Paper on Climate Change and Water (Bates et al., 2008), the Stern Review (Stern, 2007) and the Third United Nations World Water Development Report (UN WWDR3) (WWAP, 2009), although none of these reports actually contained a mountain-specific chapter.

The IPCC AR4 projections suggest an increase in global average precipitation, but a decrease in precipitation and thus annual water supply is expected in most regions where the relation of water supply to water demand is already critical today (Solomon et al., 2007). This concerns especially the subtropical climate zone where both vulnerability to water scarcity and dependence on mountain water resources are high (Viviroli et al., 2007). Furthermore, the IPCC Technical Paper on Climate Change and Water (Bates et al., 2008) states with high confidence that global warming will cause changes in the seasonality of river flows where much winter precipitation currently falls as snow. This notion is in agreement with trends already observed in mountain regions in response to 20th century warming and precipitation change, most clearly in the North American Cordillera (e.g. Stewart et al., 2005; Maurer et al., 2007; Déry et al., 2009a and b; for a comprehensive overview see Stewart, 2009). Glacierrelated changes in runoff are also important in some regions. Current impacts usually include increased runoff from enhanced ice melt (the transient "mining" of water stored in glaciers) in basins with high elevation or high glacierization or both (Casassa et al., 2009), but decreases in water yield are expected over the next few decades (Kundzewicz et al., 2007) as a consequence of the overall reduction in mass of glaciers due to global warming (Schneeberger et al., 2003).

The combination of shifts in seasonality and changes in total runoff are likely to have consequences for future water availability, increasing the challenges for management of water resources originating in mountains. Current management regimes based on historic climate and hydrological variability will likely be inadequate, yet better methods based on process understanding remain hampered by our limited understanding of both projected climate change and hydrologic response. As a foundation to long-term planning, it is neces- sary to determine reliably the location, extent, dependability and quality of water resources, as well as the human activities that affect those resources (cf. Young et al., 1994). At the same time, it is essential that these findings be useful for water managers in order to pave the way for their implementation in water resources management practice. Institutional issues within the water management community are also frequently a barrier to effective use of new information as discussed in more detail below.

This article presents an overview of climate change and mountain water resources, based on the authors' experience in their respective regions of work. These regions served as case studies which were compared to isolate commonalities. In the subsequent sections we will briefly introduce our casestudy regions (Chapter 2) and examine the state of knowledge regarding the importance of water supply from mountain areas for water resources in the adjacent lowlands and anticipated climate change impacts (Chapter 3). From there, we will identify research and monitoring needs (Chapter 4), make recommendations related to research, water resources management and policy (Chapter 5) and finally draw conclusions regarding water resources management and water policy (Chapter 6).

\section{Characterisation of the case-study regions}

The 11 case-study regions examined as a basis for the following discussions are listed in Table 1 along with the corresponding countries and river basins (the latter are only listed if there is a single major river basin to focus on). The predominant lowland climates, essential for defining the hydrological significance of mountain ranges (Viviroli et al., 2007), show a broad range from desert-type climates to cold climates.

Figure 1 shows the location of these case-study regions and places them in the global context of the significance of mountain areas for downstream water resources, which is quantified here by the index for Water Resources Contribution (WRC) (Viviroli et al., 2007). WRC is the ratio of lowland water availability (surplus or deficit) to water supply from mountains (only surplus is considered) and identifies the importance of a mountain raster cell for water resources supply in the hydrologically related lowland area.

To allow a comparison of the regions studied with respect to the subject of this overview article, Fig. 2 characterises them on the basis of the metrics mentioned below. Metrics $\mathrm{B}$ to $\mathrm{D}$ consist of a number of detail questions that were assessed by the authors (each for his/her geographic region of expertise). The detail questions and the corresponding scores are found in Table S1 (see Supplement):

- Water stress: dynamic Water Stress Index (DWSI) as introduced by Wada et al. (2011), averaged over cells of $0.5^{\circ} \times 0.5^{\circ}$. DWSI is based on the well-known Water Stress Index (WSI) which expresses how much of 
Table 1. Regions studied as a basis for the present article.

\begin{tabular}{|c|c|c|c|c|}
\hline & $\begin{array}{l}\text { Mountain massif(s) } \\
\text { or region }\end{array}$ & $\begin{array}{l}\text { Country(ies) } \\
\text { in focus }\end{array}$ & $\begin{array}{l}\text { River basin(s) } \\
\text { in focus } \\
\text { (where applicable) }\end{array}$ & $\begin{array}{l}\text { Predominant } \\
\text { lowland } \\
\text { climate }(s)^{1}\end{array}$ \\
\hline ALC & Alps (Central) & Switzerland & - & Dfb (cold, no dry season, warm summer) \\
\hline ALE & Alps (East) & Austria & - & Dfb (cold, no dry season, warm summer) \\
\hline ANT & Tropical Andes & $\begin{array}{l}\text { Bolivia, Ecuador } \\
\text { and Peru }\end{array}$ & - & $\begin{array}{l}\text { BWh, BWk (hot and cold desert) [west]; Af, } \\
\text { Am, Aw (tropical rainforest, monsoon and } \\
\text { savannah) [east] }\end{array}$ \\
\hline DRM & $\begin{array}{l}\text { Drakensberg } \\
\text { Mountains }\end{array}$ & South Africa & - & BWh, BWk (hot and cold desert) \\
\hline EM & $\begin{array}{l}\text { East } \\
\text { Mediterranean }\end{array}$ & Israel & Jordan River & $\begin{array}{l}\text { BWh, BWk (hot and cold desert), BSh } \\
\text { (hot steppe) }\end{array}$ \\
\hline HIK & $\begin{array}{l}\text { Karakoram } \\
\text { Himalaya }\end{array}$ & Pakistan & Indus River & BWh (hot desert) \\
\hline PNW & $\begin{array}{l}\text { Pacific } \\
\text { Northwest }\end{array}$ & United States & $\begin{array}{l}\text { Columbia } \\
\text { River }\end{array}$ & Csb (temperate, dry and warm summer) \\
\hline PYR & Pyrenees & Spain & Ebro River & $\begin{array}{l}\text { BSk (cold steppe), Csa (temperate, } \\
\text { dry and hot summer) }\end{array}$ \\
\hline SAL & Southern Alps & $\begin{array}{l}\text { New Zealand } \\
\text { (South Island) }\end{array}$ & - & $\mathrm{Cfb}$ (temperate, no dry season, warm summer) \\
\hline $\mathrm{TSH}$ & Tien Shan & Kyrgyzstan & $\begin{array}{l}\text { Syr Darya } \\
\text { River }\end{array}$ & $\begin{array}{l}\text { BSk (cold steppe), BWk (cold desert), Dfa } \\
\text { (cold, no dry season, hot summer) }\end{array}$ \\
\hline UCJ & $\begin{array}{l}\text { Upper Changjiang } \\
\text { River/Tibetan } \\
\text { Plateau }\end{array}$ & China & $\begin{array}{l}\text { Changjiang } \\
\text { (Yangtze) } \\
\text { River }\end{array}$ & $\begin{array}{l}\text { Cfa (temperate, no dry season, } \\
\text { hot summer) }\end{array}$ \\
\hline
\end{tabular}

${ }^{1}$ According to the Köppen-Geiger climate classification as presented by Peel et al. (2007)

the available water is taken up by the demand. DWSI extends WSI by considering duration, frequency and severity of water stress over a period of 44 years (1958 to 2001), based on climatological data obtained from New et al. (1999). Values above 0.2 indicate medium water stress, and above 0.4 indicate high water stress. The dot indicates the mean value for the entire region (including the lowland portions), and the coloured bars indicate the range of water stress observed in the entire region.

- Water management capacity: capacity of the water management sector to adapt to projected climate change. We judged 14 questions organised in four thematic blocks: institutional capacity; political conditions; manager competence; and knowledge transfer with researchers. For each block, a score of 1 means low capacity, and a score of 5 indicates high capacity. The summary score is the average of the scores achieved in the four thematic blocks. The coloured bars indicate the range of scores observed in the four thematic blocks.

- Scientific capacity - national: scientific capacity in water resources and climate change available in the respective nation. This is assessed through 11 questions organised in four thematic blocks: boundary conditions for research; competence in research; data availability and access; and state of knowledge. A score of 1 means low capacity, and a score of 5 indicates high capacity. The coloured bars indicate the range of capacity observed in the four thematic blocks.

- Scientific capacity - international: similar to national scientific capacity (metric C), only that here, the capacity available for the respective region at international level is assessed.

The main goal of this assessment is to illustrate the level of diversity in both likely water stress and the capacity to deal with water stress that occurs in our case-study regions, thus providing a framework for more detailed assessments and subsequent recommendations. Also, we refer only to changes related to climate, whereas further aspects such as land use change, economic development and population growth are also important in defining the future state of water resources.

In part (a) of Fig. 2, the capacity of water management to adapt to climate change is plotted against water stress for each region. In general, high physical water stress is found together with low adaptation capacity. This combination is detrimental to the security and reliability of water supply and occurs in regions where the technological 


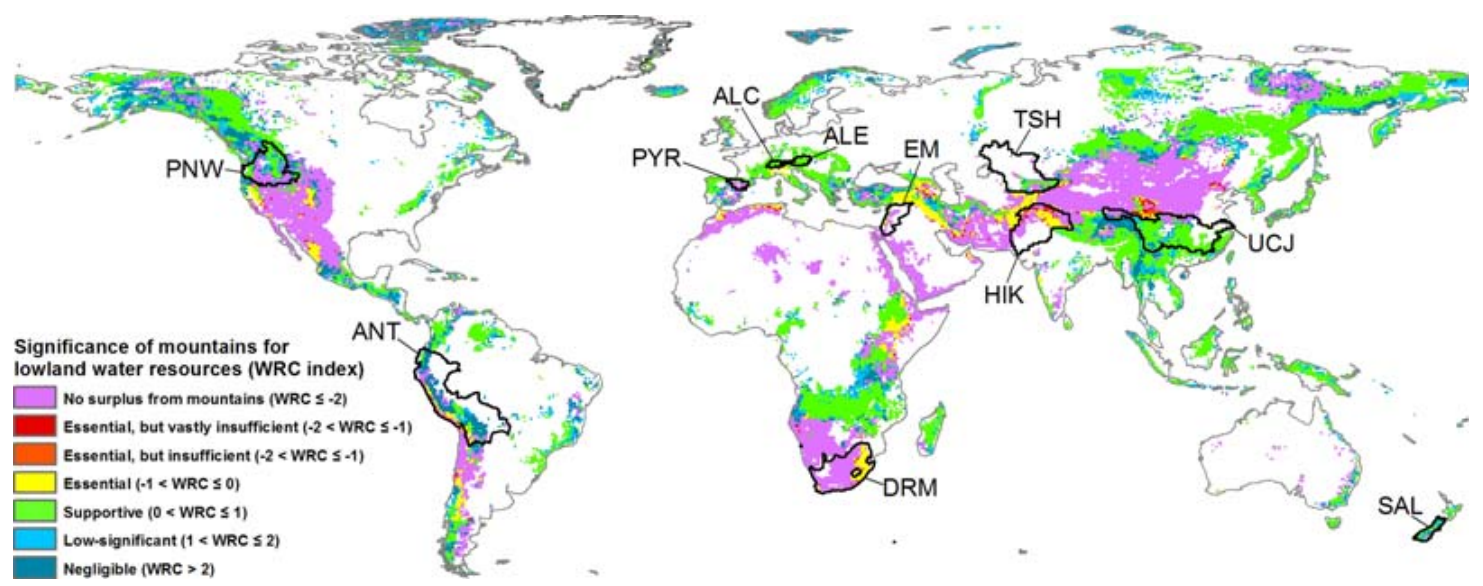

Fig. 1. Location of our case-study regions on a world map at a resolution of $0.5^{\circ} \times 0.5^{\circ}$ showing the significance of mountain regions for lowland water resources (following Viviroli et al., 2007).

measures necessary for adaptation are not available due to poor economic development and the resulting lack of funds. An exception to this general trend is found in the Pyrenees (PYR) and the Drakensberg Mountains (DRM) where relatively high average water stress is paired by well-developed management capacity. It should be noted that the reported values for water stress refer to the mean of the entire casestudy region, which may mask smaller areas with high water stress. This applies, for example, to Bolivia, Ecuador and Peru which were chosen to represent the Tropical Andes (ANT). The average water stress computed for this region is 0.15 , while the arid parts of the region (the Andes themselves, including the Pacific slopes as well as the lowlands to the west) show values well above 0.4 . Similar reservations apply to the average water stress value for the Karakoram Himalaya (0.29), especially because the Indus Plains - where the majority of the population lives - suffer from even more severe water stress (Archer et al., 2010), frequently with values well above 0.8 . The average value for the Pyrenees $(0.22)$ also masks the fact that stress is much higher in the adjacent River Ebro Plain. These examples illustrate the importance of considering the range indicated by the coloured bars in Fig. 2 and to bear in mind that the level of water stress is very diverse in some regions. The top left of Fig. 2a shows the central and eastern part of the European Alps (ALC and ALE). In these regions there is a very high level of management capacity and generally low water stress, the latter occurring almost exclusively outside of the actual mountainous region.

Part (b) of Fig. 2 assesses the scientific capacity to deal with climate change questions for our case-study regions. It shows that regions with low national scientific capacity usually have slightly higher research capacity at the international level, most notably in the Tropical Andes (ANT) and the Karakoram Himalaya (HIK). In practice, however, international scientific support will obviously require appropriate funding which will usually also be of international origin. It is important to note that these factors may be outside the direct control of the region in question. In contrast, where there is high national scientific capacity, international scientific capacity usually lags behind, although international projects (such as research funded by the EU in the case of the European Alps, ALC and ALE, and the Pyrenees, PYR) may still make the region attractive for international research and lead to a relatively high level of international scientific capacity. The Upper Changjiang region (UCJ) presents an outlier from the aforementioned connection as it has relatively high national scientific capacity but rather poor international capacity. The emerging economic power of China has led to international scientific aid becoming less available as the country is increasingly expected to rely on its own scientific resources. The Southern Alps (SAL) represent another outlier because New Zealand has very limited access to overarching international research coordination and funding networks.

Part (c) of Fig. 2, finally, is a synthesis of parts (a) and (b) and compares maximum scientific capacity available at national or international level with water management capacity to adapt to climate change. It shows that for some regions, scientific capacity (national or international or both) is clearly higher than water management capacity, which points to a need for the better implementation of scientific findings into water management practice. This is most prominent for the Pacific Northwest (PNW) but also occurs in the East Mediterranean region (EM), the Upper Changjiang region (UCJ), the Karakoram Himalaya (HIK), the Drakensberg Mountains (DRM) and the Pyrenees (PYR). In the case of the Pacific Northwest (PNW), both high scientific capacity and high water management capacity are actually present, but expertise in climate science and in hydrologic modelling is not integrated with the management community, which limits its capacity to respond to climate change 

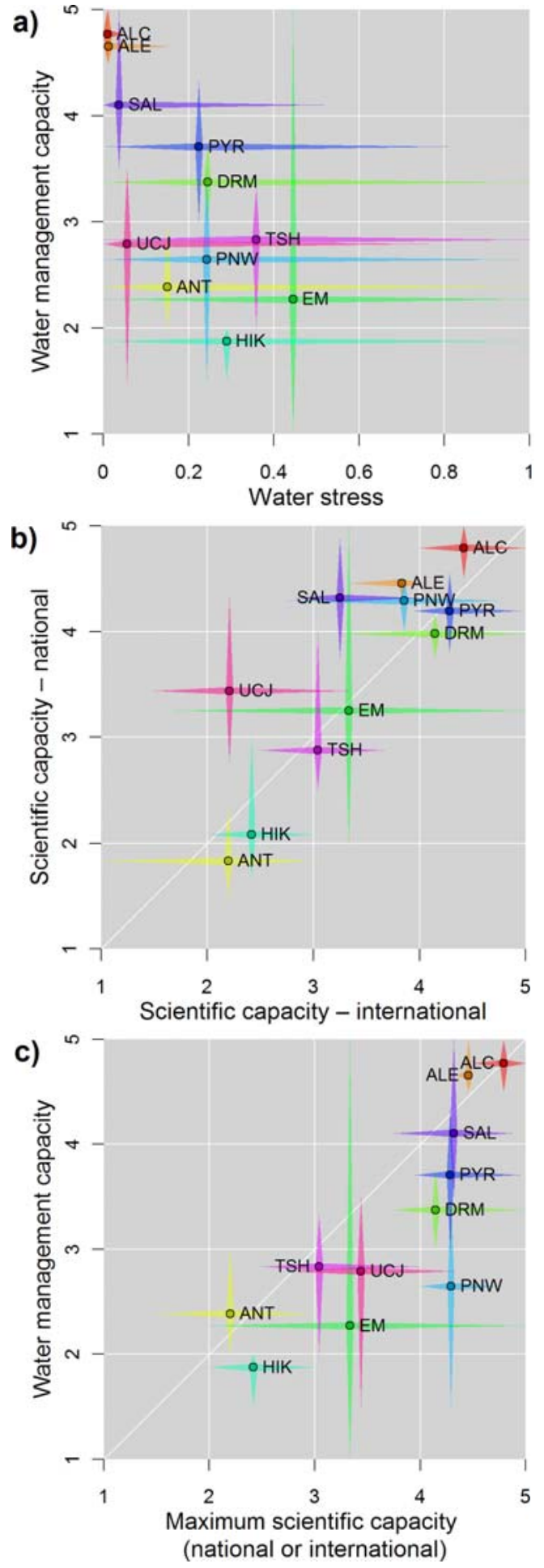

Fig. 2. Characterisation of the regions studied with regard to (a) water stress and water management capacity to adapt to climate change; (b) national and international scientific capacity regarding climate change and water resources issues; (c) water management capacity to adapt to climate change and maximum scientific capacity (regardless whether of national or international origin) regarding climate change and water resources issues. The coloured bars indicate the range of values. impacts that exceed the existing range of natural variability (Hamlet, 2010). This situation illustrates that limited capacity to respond to climate change impacts and institutional obstacles to effective adaptation are present even in highly developed and successful management systems. In contrast, a common assumption is that increased water stress in areas that already have a high degree of water stress will result in the most severe impacts. Hamlet (2010), however, points out that management systems in the PNW that have evolved in areas of relatively high water stress are much better able to cope with droughts because they are already common events, suggesting higher adaptive capacity to future water limitations than areas of the region with relatively little historical water stress. These findings probably also apply to other areas with high water stress and high water management capacity noted above.

Thus the diversity of settings observed in our cross-section of regions calls for a regionally and sometimes even locally differentiated view to future management. At the same time, the detrimental concurrence of high water stress and low management capacity in regions with poor economic development seems to be a common problem that urgently calls for improvements in research, monitoring, management and information exchange, topics we address in Chapters 4 and 5 of this article. For more subtle distinctions, several categories would need to be separated, such as access to infrastructure, management capacity in the context of climate variability, ability to assess future impacts and devise appropriate adaptation strategies or capacity to implement change.

\section{State of knowledge}

As a basis for identifying research and monitoring needs (Chapter 4) and making recommendations (Chapter 5), we first need to discuss the state of knowledge on provision of runoff from mountains (supply), consumption of water in the lowlands (demand) and options for balancing demand and supply. This will enable us to discuss what kind of information is needed to answer the questions raised by water resources management and planning and how it can be obtained and disseminated.

Due to the large uncertainty concerning groundwater recharge and flows (see Sect. 4.1.5), we will focus on surface water in the following discussion. It is however important to note that groundwater is often heavily used for water supply in both developed and undeveloped countries, although groundwater resources are generally both poorly understood and poorly monitored. This situation leads to an absence of attempts to regulate or manage these resources. Also, the potential impacts of climate change (e.g. on rates of recharge) in groundwater systems are often essentially unknown.

Furthermore, we will consider mountains as major suppliers and the adjacent lowlands as major consumers of fresh water. This simplification is defensible in our attempt to 
provide a comparative overview, although water demand within mountain regions should not be neglected. This is particularly the case in the Andes, where the mountain region forms the economic backbone of several countries (e.g. Colombia, Ecuador and Bolivia). Especially since the hydrological processes of these regions are both extremely variable and understudied, there is a strong need for future research on the resilience and potential changes of these systems under external pressure (see Buytaert et al., 2010a).

\subsection{Water supply (runoff from mountains)}

\subsubsection{Present state}

Viviroli et al. (2007) recently presented a global overview of the role of mountains in water supply. On the basis of global runoff fields (Fekete et al., 2002), a mountain typology (Meybeck et al., 2001) as well as further data on population distribution and climate zones, they derived a set of global maps at a resolution of $0.5^{\circ} \times 0.5^{\circ}$, revealing that $23 \%$ of mountain areas world-wide are an essential component of downstream water supply in the earth system context, while another $30 \%$ have a supportive role. When the actual lowland water use is considered explicitly, $7 \%$ of the global mountain area has an essential role in water resources, while another $37 \%$ provides important supportive supply (Fig. 1). This is of special importance in arid and semiarid regions where the vulnerability to seasonal and regional water shortages is high. Moreover, mountains in the arid zone clearly deliver a disproportionate share of total discharge (66.5\%) when compared to their share of total area $(29.8 \%)$. Critically important mountain regions are found in the Middle East, South Africa, parts of the Rocky Mountains and the Andes. The importance of mountain water resources from the western part of the Himalaya and from the Tibetan Plateau is particularly marked because these regions partly compensate considerable lowland water deficits (Archer et al., 2010).

Snowmelt plays a major role in seasonal runoff patterns and water supply outside of the humid tropics. This was recently shown by Barnett et al. (2005) who used the output of a macro-scale hydrological model with a resolution of $0.5^{\circ} \times 0.5^{\circ}$ to assess the ratio of accumulated annual snowfall to annual runoff. The authors also compared the simulated annual runoff to the capacity of existing reservoirs, which served to identify cases where sufficient reservoir storage capacity is available to buffer seasonal shifts in runoff caused by earlier snowmelt (see also Sect. 3.1.5). In their analysis, Barnett et al. (2005) found that about one-sixth of the world's population lives within snowmelt-dominated catchments with low reservoir storage, this domain being potentially vulnerable to shifts in runoff caused by climate change impacts on seasonal snow. A critical region, for example, is the Western Himalaya where a modelling study for the Satluj River basin (a tributary to the Indus River) by Singh and Jain (2003) suggests that about $75 \%$ of the summer runoff is generated from snowmelt. On the neighbour- ing Jhelum River basin, Archer and Fowler (2008) show a similar dependence of summer runoff on preceding winter snowfall. Barnett et al. (2005) have identified further regions with high dependence on snowmelt runoff in northern China, north-western India, sub-basins downstream of the southern Andes, north-central USA, and some coastal areas of Western North America and Europe. Adam et al. (2009), however, showed in modelling studies that losses of warm season water availability did not, in general, follow losses of snow water equivalent at the global scale. Thus changes in warm season precipitation are an important factor that needs to be considered in the analysis of projected water availability in many areas.

The significance of glaciers to water supply depends principally on the proportion of catchments that they occupy, i.e. the greater the distance from glaciers, the smaller their influence (Zappa and Kan, 2007; Koboltschnig et al., 2008; Lambrecht and Mayer, 2009; Kaser et al., 2010; Koboltschnig and Schöner, 2010). Because population numbers also increase with distance from the glaciers, human dependence on glacier melt is often highest at intermediate altitudes (Kaser et al., 2010). In addition, the climate regime prevailing in the corresponding river basin is decisive: Kaser et al. (2010) conclude that the glacier contribution to water resources is minor in monsoon regimes, moderate in most midlatitude basins, but of high importance in very dry basins (e.g. Aral Sea basin and Tien Shan mountains). Globally valid statements about the significance of glaciers are therefore not possible. It is also difficult to make a clear quantitative distinction between the contribution from melting of interannual snowpack and from glaciers, even though nival melt from lower elevations generally precedes the glacial contribution from higher elevations (Weingartner and Aschwanden, 1992). The recent controversy on rates of melting of Himalayan glaciers (see Sect. 3.1.3) and the implications for water resources of South Asian countries (see Crutz et al., 2007) are placed in perspective by preliminary results by Armstrong et al. (2009) who found that the annual contribution of glacier melt water to streamflow in the Nepal Himalayas represents 2-3\% of the total annual streamflow volume of the rivers of Nepal and that even seasonal contributions are not likely to exceed $2-13 \%$ of the total annual flow volume measured at lower altitude hydrometric stations (see also Alford, 2008 and Alford and Armstrong, 2010). For the Indus River basin, which is located in the drier western part of the Himalayas, the recent study by Immerzeel et al. (2010) suggests that discharge generated by snow and glacial melt amounts to $151 \%$ of the discharge generated by the lower basin, and that about $40 \%$ of this meltwater originates from glaciers. It should be noted that these figures are dependent on the assessment of total basin annual precipitation, which in turn derives primarily from analysis of remote sensing data. To our understanding, the data product used (Tropical Rainfall Measurement Mission, TRMM; Huffman et al., 2007) has only limited accuracy in high mountain environments where 
orographic precipitation mechanisms dominate rather than convective systems (the majority of the Upper Indus falls into this category as there is, in most years, relatively limited monsoon penetration). Nevertheless, the glacial regime plays an important role in the high-altitude catchments of the Indus River, although its influence decreases strongly toward the margins of the mountains (Archer et al., 2010). In contrast, proportional flow from glaciers over large areas in the tropical Andes is much higher because the area affected by interannual snowpack is limited (see Sect. 3.1.3).

Glaciers may provide a smoothing effect for water resources by complementing irregular runoff from highly variable summer precipitation with much more stable runoff from melting snow and ice (see e.g. Hock et al., 2005). In effect, glaciers reduce the interannual variability of summer flows by storing water in cold and wet years and releasing water in hot and dry years, as was shown in the 2003 European heatwave when the average summer runoff from glacierized basins in Switzerland was still close to the longterm mean while basins of the Swiss Plateau without glaciers delivered only $40 \%$ to $60 \%$ of long-term summer average runoff (Zappa and Kan, 2007). With reference to studies from the Cascade Mountains (Fountain and Tangborn, 1985) and the Alps (Chen and Ohmura, 1990), Casassa et al. (2009) conclude that a minimum coefficient of variation in summer runoff is reached with a share in glaciated area of about $40 \%$.

Due to the low temperatures, permafrost exists in all mountainous areas of sufficient elevation. The largest area of mountain permafrost (approx. $3.5 \times 10^{6} \mathrm{~km}^{2}$ ) is found in the Central Asian region, and permafrost in high Andes amounts to another $100000 \mathrm{~km}^{2}$ (Romanovsky et al., 2007). In the European Alps, periglacial permafrost currently occupies an area comparable to that of glaciers, but in comparison to alpine glaciers, very little is known about the secular evolution of permafrost and the corresponding release of water (Haeberli and Beniston, 1998). The amount of melt water originating from permafrost is very small as compared to the interannual melting of glaciers and snow pack (Tenthorey, 1992) and therefore not relevant for water supply at global and regional scale.

\subsubsection{Past trends in mountain runoff}

Analysis of runoff trends over the historical record are very difficult for both mountainous and lowland areas. Results depend heavily on the methodology implemented and the timeframe of the study (see e.g. Radziejewski and Kundzewicz, 2004), and the high variability of precipitation and temperature often lead to inconclusive or misleading findings. Particular challenges are imposed by interannual and decadal scale variations in precipitation and mountain snowpacks that are caused by large-scale circulation modes such as the El NiñoSouthern Oscillation, the Eurasian Pattern, the North Atlantic Oscillation, the North Pacific Oscillation, the Pacific North American Pattern, the Pacific Decadal Oscillation and the In- dian Monsoon to name but a few. Some studies have statistically removed interannual variability due to natural climate modes from time series, attempting to isolate trends from other factors than global warming (Vuille and Milana, 2007), but such approaches add uncertainty to the analysis, and the relatively short time span of most data records (typically a few decades) remains a major impediment to the detection of conclusive trends.

For mountain areas, trend detection is often assumed to be easier due to the high climatic sensitivity of these environments, although concurrent changes in temperature and precipitation as well as the lack of unbiased long-term records (see Sect. 4.2.2) complicate trend studies. Two regions stand out because there is both extensive and sound scientific evidence of past trends in mountain runoff as well as a large dependence of the adjacent lowland region on this mountain runoff:

- For the Western United States, a number of studies found that more precipitation is falling as rain instead of snow in winter, and that snow melt occurs earlier (e.g. Hamlet et al., 2005; Mote et al., 2005; Knowles et al., 2006), resulting in systematic changes in runoff timing (Dettinger et al., 1995; Cayan et al., 2001; Regonda et al., 2005; Stewart et al., 2005; Hamlet et al., 2007). Barnett et al. (2008) were successful in identifying an anthropogenic "fingerprint" by using a multivariable detection and attribution methodology (see also Hamlet, 2010). Particular difficulties apply however to trend analyses in the mid-elevations of the semi-arid and arid climate zones. In these critical regions, the natural runoff pattern of most of the large streams has been altered, largely by dams or diversions (cf. Döll et al., 2009), which makes it difficult to assess changes in the natural response of amount and timing of streamflow (cf. Stewart, 2009).

- For the European Alps, Renard et al. (2008) detected a clear trend towards earlier snowmelt in the French part, which is consistent with a significant increase in temperature in this area. In Switzerland, which represents major parts the central Alps, Birsan et al. (2005) identified increases in winter, spring and autumn streamflow since 1930, which the authors attribute tentatively to a shift from snowfall to rainfall as well as increased and earlier snow melt due to a rise in air temperature. These streamflow trends were found to be positively correlated with mean basin elevation (and strongest for medium flows), supporting the hypothesis that mountain basins are among the most vulnerable environments in terms of climate-induced streamflow changes. In summer, however, when most of the annual runoff occurs, both decreasing and increasing trends are observed. This heterogeneity of these trend signals is also highlighted by the recent analysis by Barben et al. (2010) for Switzerland. 
Evidence for decreasing snow cover and corresponding shifts towards earlier streamflow has also been presented for the $\mathrm{Ob}$, Lena and Yenisei Rivers in Siberia (e.g. Yang et al., 2002, 2003 and 2007), which illustrates the recurrence of global warming impacts on streamflow regimes in snowdominated regions.

Although changes in temperature and precipitation certainly have the largest impact on streamflow from a global viewpoint, it should be borne in mind that other factors can also effect changes in streamflow in some regions. In Mediterranean mountains such as the Pyrenees, for example, depopulation and subsequent land abandonment have led to vegetation growth which has been the main driver of observed reductions in runoff generation and decreases in annual streamflow (Begueria et al., 2003; López-Moreno et al., 2008). Further influence on the evolution of water availability in the Ebro River basin stems from dam regulation, decrease in snowpack, increase in evapotranspiration rates and increased water use for domestic, agricultural and industrial use, although these factors are inferior to the impact of vegetation growth (López-Moreno et al., 2010).

\subsubsection{Climate change projections}

Scenario projections for the impacts of climate change on precipitation and runoff are subject to large uncertainties at the global scale. This is apparent in comparing the results of different General Circulation Models (GCMs) which show inconsistencies in the sign and magnitude of precipitation change (Bates et al., 2008; Stewart, 2009; see also Buytaert et al., 2009). Climate change scenario projections in mountain areas are difficult to construct owing to the difficulties in modelling regions with marked small-scale variations in climate that follow topography (see Sect. 3.1.4 and Chapter 4).

Bates et al. (2008) concluded that warming would lead to systematic change in the seasonality of snowmelt-dominated rivers and that snow-dominated regions are particularly sensitive to changes in temperature. Depending on elevation and winter temperatures, early snowmelt may lead to more frequent spring flooding at the local scale (Hamlet and Lettenmaier, 2007), and summer irrigation water shortages may occur in regions that are dominated today by nival regimes (see e.g. Vano et al., 2010). Some studies have argued that large changes are expected especially at low latitudes, e.g. in South-east and Central Asia (Parry et al., 2007). In regions where dependence on glacier runoff is high, shifts in seasonality and decreases in the amount of glacial melt will cause a systematic reduction in water availability as well as a reduced buffering effect of glacier runoff during the dry season (e.g. in the Tropical Andes, see Coudrain et al., 2005 and Vuille et al., 2008, or in Central Asia, see Hagg and Braun, 2005).

In the Andes, it is likely that water stress will become more severe, especially in urban cities at high altitudes (e.g. Bogotá, Quito, La Paz). Again, GCMs disagree widely on the direction and magnitude of the change in precipitation, but several of them predict severe decreases in precipitation (Buytaert et al., 2010b; Buytaert et al., 2010c). Even disregarding the uncertainty in projections, the impact of climate change on water supply is difficult to predict. Glacier-fed river systems will become more seasonal when glaciers disappear, although the glacier signal dilutes relatively quickly with basin size (Mark and Seltzer, 2003; Alford and Armstrong, 2010; see also Sect. 3.1.1). The impact of climate change on other ecosystems that provide water regulation, such as tropical alpine wetlands, is much less known although a degradation and loss of regional capacity of these systems is expected (Buytaert et al., 2010b).

Owing to the limited research available at present, projections regarding the future state of glaciers are however uncertain. This was recently shown by the controversy surrounding the mistaken IPCC statement that the Himalayan Glaciers could disappear by 2035 at present warming rates (see Bagla, 2009; Cogley et al., 2010; IPCC, 2010; Schiermeier, 2010; see also Sect. 3.1.1). In addition, research concerning the future state of glaciers must go beyond focusing on precipitation and surface air temperature and must also consider global incoming shortwave and longwave radiation (Huss et al., 2009) or, in the case of tropical glaciers, atmospheric moisture (Mölg et al., 2006).

Considering the present state and anticipated changes, a number of regions have been identified as particularly vulnerable to changes in mountain runoff with subsequent deterioration of water resources supply in the adjacent lowlands.

- Viviroli et al. (2007) identify vulnerable regions where a high dependence on mountain runoff in the lowlands coincides with anticipated decrease in precipitation and growth in population. This applies mainly to river basins in the sub-tropical and wet-dry tropical climate zones where the capacity to adapt to changes is also low. Particularly vulnerable regions encompass great parts of the large Himalayan river basins that are, according to recent population data (ORLN, 2002), home to over 1.3 billion people today, but also the Middle East (e.g. Euphrates and Tigris River basins), North, East and South Africa as well as the dry parts of the Andes (in the centre, highlands, and western side of the northern Andes and in the eastern side of the southern Andes).

- The UN WWDR3 (WWAP, 2009) mentions two mountain-related systems where limited possibility of adaptation results in high vulnerability to projected impacts. The first are snow melt systems such as the Indus River basin (which actually also receives significant contributions from ice melt, although the corresponding figures are still under dispute, see Sect. 3.1.1), the Ganges-Brahmaputra River basin and Northern China. The second are the semi-arid and arid tropics with limited snow melt and limited groundwater like parts of the Indian subcontinent, Sub-Saharan Africa and Southern 
and Western Australia. The reasons for the vulnerability of these systems vary strongly from region to region and encompass a number of anticipated changes, such as unfavourable changes in the amount and timing of precipitation and runoff, altered precipitation variability, groundwater tables, population growth and food demand. Similarly diverse are the factors that limit adaptability, such as limited capacity to further extend the existing infrastructure, water resources that are already over-allocated or a lack of financial resources to support adaptation.

\subsubsection{Representation of mountains in climate and hydrological models}

Climatological and hydrological models are important tools for laying the foundations for successful and sustainable water management. Insight into important processes of mountain areas is achieved through process-oriented hydrological modelling exercises with focus on snow and glacier melt. A number of such studies have been conducted for meso-scale catchments in the European Alps (e.g. Gurtz et al., 2003; Verbunt et al., 2003; Zappa et al., 2003; Schaefli et al., 2005; Horton et al., 2006; Lehning et al., 2006; Dadic et al., 2008; Huss et al., 2008; Koboltschnig et al., 2008; Michlmayer et al., 2008; Bavay et al., 2009; Lambrecht and Mayer, 2009; Weber et al., 2009; Köplin et al., 2010; Magnusson et al., 2010) the Scandinavian mountains (e.g. Hock, 1999; Hock and Holmgren, 2005; Skaugen, 2007; Beldring et al., 2008), the Rocky Mountains (e.g. Hamlet et al., 2005 and 2007; Letsinger and Olyphant, 2007; Stahl et al., 2007; Comeau et al., 2009; DeBeer and Pomeroy, 2009; see also overview by Bales et al., 2006), the Western Himalaya (e.g. Singh and Bengtsson, 2003; Singh and Jain, 2003; Rees and Collins, 2006; Konz et al., 2007; Akhtar et al., 2008) and Central Asia (e.g. Hagg et al., 2007). Global macro-scale studies (e.g. Barnett et al., 2005; Adam et al., 2009) are equally important in providing a self-consistent global picture.

Climatological and hydrological modelling is, however, particularly challenging in mountain environments for several reasons. First, extremely limited meteorological driving data and hydrologic data are available for high elevation areas. Second, the pronounced spatial and temporal heterogeneity of conditions in mountain areas calls for high model resolutions and thus also for detailed physiographic information (e.g. soil, vegetation and land use types). The latter is usually only available for limited areas, which restricts the availability of reliable modelling efforts mostly to case studies at the meso scale. Third, relevant processes in mountain areas are not understood sufficiently, particularly orographic precipitation and snowfall, which are among the most difficult variables to simulate in climate models. The lack of data hampers the research community's ability to validate potential improvements in high elevation processes in models.
Another area of uncertainty concerns the magnitude of the feedback effects (see Sect. 4.1.6) and their influence on the energy balance. Due to the limited process understanding, formulation of such effects varies substantially between individual models. Furthermore, the interaction between climate change and vegetation and its effect on evaporation and the hydrological cycle is also not fully understood (Adam et al., 2009). Altogether, the impact of climate change on the water cycle in mountainous regions - particularly on snow and ice - is highly non-linear and requires much more detailed research to help quantify uncertainties in projections related to climate forcing and hydrologic modelling uncertainties. Especially when using macro-scale models, the increasing size of the area studied requires more empirical approaches, limiting the level of detail and explicit process representation. Interpretation of results from macro-scale models at smaller spatial scales is therefore problematic, and the sensitivity of hydrologic models to temperature and precipitation forcing may reflect the scale of the implementation.

Aside from the abovementioned challenges, it should also be borne in mind that socio-economic issues have an impact on mountain hydrology and climatology and consequently on water availability, and that it is important to work towards incorporating these effects in our models. Examples are the influence of irrigation, dam construction, drinking water use, tourism and alpine lake management on water availability, the influence of large dam reservoirs on local and regional climatology, or the influence of topography on water distribution and use. The relevance of such effects, however, depends on the scale and region in focus.

\subsubsection{The role of reservoirs}

In view of the colossal magnitude of water engineering today (see Vörösmarty and Sahagian, 2000), the role of dams and reservoirs needs to be considered when discussing present and potential future water supplies, yet such analyses remain problematic, particularly at the global scale. Even at the regional scale, information about reservoir operations and tools for decision support are often lacking. The number of reservoirs world-wide is impressive: the World Register of Dams (WRD) (ICOLD, 2003) lists around 50000 mediumor large-size dams (figures vary depending on dam height and capacity criteria), and according to the UN WWDR3 (WWAP, 2009), 270 additional dams of 60 metres height or larger were planned or under construction as of 2005. As regards storage capacity, Chao et al. (2008) have shown on the basis of an augmented and improved version of the WRD that a total of $10800 \mathrm{~km}^{3}$ of water has been impounded on land to date. A smaller database by UNEP (2003) that lists dam purpose data for 1021 major reservoirs reveals that $55 \%$ of dams are at least partly (some fully) used for water supply or irrigation or both. This function involves mostly a redistribution of seasonal maximum flows towards times of maximum water 
demand (typically the high agricultural demand in spring and summer) and a stabilisation of water supply on an interannual basis. This redistribution of runoff is most effective when implemented through long-term basin planning and integrated operation of multiple reservoirs, such as in China.

Since dams can take on a role that is similar to that of the natural storage of water in snow and ice, it is possible in some instances to compensate climate-change induced shifts in runoff regime by building additional dams, increasing the size of existing reservoirs (raising dam height), or using aquifer storage and recovery schemes to increase storage capacity (Whitely Binder et al., 2010). This engineering approach to adaptation, however, faces a number of problems and questions:

- In developing areas, feasible dam sites may exist, but the needed financial resources to build the infrastructure may be lacking. Dams are also often the most costly approach to aligning supply and demand, and entail serious ecosystem impacts (Hamlet, 2010). The economic feasibility of this mitigation strategy is questionable for many regions of the world, owing to the extremely high investment costs of dams and aquifer storage and recovery schemes. In addition, building large dams may require resettlement of a large number of people (about 1.2 million local residents in the case of the Three Gorges Dam at the Changjiang River in China) and flooding of archaeological heritage (such as in case of the Ilisu dam at the Tigris River which would drown the ancient town of Hasankeyf and further archaeological heritage).

- In highly developed areas, most of the good impoundment sites have usually already been developed, and major expansion of these resources is infeasible. An example is the Columbia River basin which features 14 large storage dams and about 250 major dams in the entire catchment. In the portfolio of adaptation options available to water planners in developed countries, dams are often the most costly approach to aligning supply and demand (Hamlet, 2010).

- Dams are associated with major ecosystem impacts. Alteration of amount and, even more importantly, variability of river flow causes a number of environmental impacts downstream such as changes in river ecology (boosted through the concurrent fragmentation of rivers, see WWAP, 2009). In addition, the erosive capacity of downstream flows may be increased due to an imbalanced sediment budget, causing damages to river bank infrastructures (Kondolf, 1998).

- The lifespan of most reservoirs is limited due to sedimentation if no attempts for an effective sediment management are undertaken. The problem is exacerbated by the high bedload transport rates typical in mountain areas. For large reservoirs, sedimentation is usually an irreversible process, and the associated reduction of storage volumes diminishes the stabilising effect on water supply significantly over the decades (Morris and Fan, 1998).

Artificial aquifer recharge systems avoid the many environmental impacts of surface water projects, but can result in deteriorated water quality over time if they are not carefully managed, and recharge rates may not be sustainable over long periods of time.

In many cases, the above concerns have led to public opposition to the construction of new dams, delaying projects considerably and, in extreme cases, even bringing projects to a halt. In Spain, for example, most of the existing plans for building new dams are stalled in the law courts because progress in each of the ongoing or planned hydraulic projects requires open public debate and long stakeholder participation processes (Ibáñez and Prat, 2003). Another example is Pakistan which, in spite of two large dams (Tarbela and Mangla) on the mountain rim, has limited storage in comparison with world standards (World Bank, 2005). In terms of storage capacity, Pakistan has $150 \mathrm{~m}^{3}$ per capita compared with the United States and Australia with over $5000 \mathrm{~m}^{3}$ per capita. Successive attempts to develop major new reservoirs on the Indus have met with strenuous political as well as environmental objections.

Water management strategies and associated dam operation rules can also have a large impact on the available water supply and downstream water resources. In view of anticipated changes in supply and demand, water management is particularly challenging and requires sound and reliable projections of inflow, as well as seasonal forecasts of runoff (cf. Milly et al., 2008). The costly impacts of failing to account accurately for future conditions are apparent in historical examples where water management strategies have been based on a false premise of unrealistically high water supply capacity derived from relatively short periods of exceptionally high inflow. A prominent case is the Colorado River basin in the Western USA where the average annual flow used for establishing water rights of upper and lower basin stakeholders within the Colorado River Compact was overestimated because the short observational record turned out to cover the wettest period in 400 years and did not represent the strong decadal and longer variations in streamflow (Pulwarty et al., 2005; Woodhouse et al., 2006). Another significant example is the Grande Dixence hydropower scheme in the Swiss Alps with the highest gravity dam in the world to date. The dam was dimensioned on the basis of measurements from 1920 to 1953 which was a period with some exceptionally warm summers, leading to notable release of water from glaciers (see e.g. Huss et al., 2009) and therefore overestimation of long-term average inflow (Bezinge, 1981). 
Other factors such as changes in patterns of evaporation and evaporation losses, changing outflow requirements (e.g. related to changing instream flow needs, demand for electricity, or water supply demands, required flood control space, etc.) as well as minimal discharge requirements for ecology and the environment also need to be considered.

In the context of water engineering and reservoirs, it is also important to bear in mind that long interbasin water transfers become more and more attractive for solving water problems in developing countries with increasing populations and expanding economies, such as China and India (Ghassemi and White, 2007). A large-scale example already under construction is the South-to-North water transfer project which will deliver water from the South of China to the water-short North of China by means of three transfer routes. Negative environmental impacts are however expected for both the Changjiang (Yangtze) and Huanghe (Yellow) Rivers (Zhang, 2009). In Europe, the Spanish Parliament had approved of transferring water from the Tagus and the Ebro River basins to Mediterranean areas, but these plans have been brought to a halt through strong social and political opposition (Ibáñez and Prat, 2003). Since such transfers significantly extend the lowland portion of a river catchment, the pressure upon mountain water resources must be expected to increase further, also raising residual flow issues and associated problems for ecosystems and water quality downstream of diversions.

Regarding adaptation to increased flood events, reservoirs located in the mountains can play an important role in retaining flood peak volumes. For this purpose, sophisticated flood forecasting and management systems are required. In the upper part of the River Rhone in Switzerland, for example, the System MINERVE (Modélisation des Intempéries de Nature Extrême dans le Rhône Valaisan et de leurs Effets) has been developed (Jordan et al., 2005; García Hernandez et al., 2009). MINERVE makes use of a combined multipurpose system of reservoirs for hydropower production and flood prevention. During times of drought (which may occur more frequently in future), the multipurpose character of these reservoirs is already made use of nowadays in that water from reservoirs is used for irrigation in summer or for artificial snow making in tourist resorts in winter. A formal convention between the responsible public authorities and the owners of the reservoir is a prerequisite for the successful operation of such a system.

\subsection{Water demand (consumption in lowlands)}

When considering water resource questions, we must also consider water demand. As demand is largely outside of mountain regions, a detailed investigation of future demand is beyond the scope of this paper, and is in any event subjected to an even greater number of uncertainties due to population and technology than are supply projections.

\subsubsection{Agriculture}

According to the UN WWDR3 (WWAP, 2009), roughly 70\% of global water withdrawals are used for irrigated agriculture today. Therefore, future water demand for food production will potentially have the biggest impact on overall water demand.

A critical mountain-related issue is that large scale studies at the regional scale do not sufficiently account for the seasonality of agricultural demand and water availability. A number of national and global studies continue to use annual water supplies as the key metric for potential impacts. In critical regions with limited storage, however, vulnerability to water stress will increase markedly if seasonality of mountain runoff changes so that alignment of supply and demand is disrupted. Agriculture is especially vulnerable because it benefits from spring and summer runoff from mountains at the time when water demand to support plant growth is largest.

Three factors are decisive in this context. First, population dynamics and economic development will alter the patterns of regional demand, with strong increases expected in downstream regions that already today exhibit high demand. The growing demand in all water use sectors caused by population and development pressure is projected to exceed even changes induced by climate change in some regions (see also Vörösmarty, 2000), including areas like the Middle East or South Asia which benefit today from mountain runoff (Viviroli et al., 2007; Archer et al., 2010). Second, dietary habits might also have considerable influence, especially the trend towards higher shares in meat consumption which means that more water is required to produce the same calorific value. According to Molden (2007), global average meat consumption will rise from $37 \mathrm{~kg}$ per capita per year in 2000 to $48 \mathrm{~kg}$ in 2050. A particularly strong increase is expected in East Asia where economic growth will boost annual meat consumption to the level of OECD (Organization for Economic Co-operation and Development) member countries. This is equivalent to an almost twofold increase between 2000 and 2050. Third, rising temperatures will potentially increase evaporative demand and thus might reduce crop yields, such as anticipated for the Lower Indus plains where projections suggest a reduction of wheat yields in most climatic zones (Sultana et al., 2009), although this reduction might be partly compensated by the direct enhancing effect of increasing $\mathrm{CO}_{2}$ on crop yields.

Besides the aforementioned main drivers, a number of other factors influence water demand for food production. However, these are highly uncertain, and it is therefore difficult to predict both their future development and their overall impact. These other factors include development of water-saving plant species through genetic engineering, shifts in plant composition of agricultural areas as a natural reaction to climate change or as deliberate adaptation by 
farmers to agricultural policy (e.g. subsidies for certain farming schemes or certain regions) or energy policy (e.g. subsidies for biofuels).

It is also important to note that impacts to food security are not only related to water. In the subtropics, for example, recent studies have shown that temperature impacts alone may result in massive reductions in yield from stable crops (Battisti and Naylor, 2009). Thus certain impacts may be completely disconnected from water supply impacts related to mountain processes. Similar arguments related to impacts from low-elevation precipitation change and dryland agriculture are pertinent in that impacts in mountain environments may not constitute the dominant impact pathway.

\subsubsection{Hydropower}

Although hydropower does not represent a consumptive water use, it affects runoff seasonality in the case of reservoir storage and, moreover, creates considerable challenges for water resources management in terms of reservoir operation for water allocation and risk management. The construction of a large number of additional dams is anticipated with economic development and the associated increase in energy demand. A further incentive for building dams stems from the low $\mathrm{CO}_{2}$ emissions associated with hydropower: In its World Energy Outlook 2008, International Energy Agency (IEA, 2008) draws a scenario with more than doubling of current hydropower capacity until 2030 to meet climate goals.

Vast unused potential for hydropower production is present in Africa, developing Asia, Latin America, China, India and Russia (IEA, 2006). In the Yalong River, a branch of the Changjiang River's mountainous upstream area, for example, plans foresee construction of 21 new reservoirs during the next 15 years. Moreover, use of air conditioning may become more widespread and frequent in industrialised countries, owing to the rising air temperatures. The resulting increase in summer energy demand may pose problems in regions where no or insufficient reservoir volumes are available, especially when summer runoff is decreasing at the same time (e.g. in the Pacific Northwest of the United States, Hamlet, 2010).

In a number of developing and developed countries, energy demand and supply are becoming increasingly misaligned, and the development of local hydropower resources is frequently viewed as the only economically secure and sustainable pathway to future energy development. In Chile, for example, recent national energy policy has proposed the construction of a number of large hydropower dams in Patagonia to meet projected increases in energy demand. Perspectives in areas where hydropower development has been mature for many years can be fundamentally different. In the Columbia River basin, for example, attempts to mitigate impacts to ecosystems have historically become an increasingly important issue in the decades following hydropower development (Hamlet, 2010). Current water resources develop- ment in China (e.g. the Three Gorges project) and Southeast Asia (e.g. development of the Mekong River) show many similarities to the underlying values towards water resources development that were present in the USA in the 1950s and 1960s. It remains to be seen, however, if social values in these rapidly developing countries will follow a similar trajectory to those encountered in the USA in the decades following development.

\subsection{Balancing demand and supply}

There are apparent theoretical limits to the fraction of annual flow that can be extracted from a particular water supply system. Lettenmaier and Burges (1977), for example, showed that attempts to extract more than about 0.7 times annual flow would generally result in poor performance of the water supply system, and that increasing storage would not successfully mitigate these impacts. These findings support the argument that overallocation of water supply systems is a crucial sustainability issue. In the context of climate change, reductions in annual flow in mountain areas with decreasing precipitation are therefore also a concern, even if demand in the lowlands were not projected to increase significantly.

Already today, there are extended regions that are experiencing water stress and, at the same time, depend at least to some degree on mountain water resources. Examples are found in the Southwest USA (associated mountain range: Rocky Mountains), the Pacific side of the Tropical Andes, South Africa (Drakensberg Mountains), parts of the Mediterranean (e.g. Atlas Mountains and Pyrenees), the Middle East (Anti-Lebanon Mountains), large parts of Asia (e.g. Himalayas) and Southeast Australia (Snowy Mountains) (see WWAP, 2009). In all of these cases, solutions are urgently required to prevent the detrimental consequences of water stress. One approach to adaptation in this context is water resources management that orients itself not solely by water demand but also by the limits of the supply and thereby considers all of the decisive factors across the entire river basin. In regions where such multi-objective planning is the norm, the ability to encompass changes in the constituents of the current management plans is a potential obstacle to successful adaptation (Hamlet, 2010).

Although there are some exceptions, in most cases it will not be possible to greatly increase available water resources to reduce water stress. Desalinisation might be an option in the lowlands with further technological progress and lowering of cost (Zhou and Tol, 2005), but its use is currently limited to energy-rich regions. Practical problems apply also to alleviation of regional water demand by importing food and thus also the water that was used to grow it (so-called virtual water, cf. Allan, 2003). Although analyses of the international trade of virtual water reveal impressive quantities of water transferred (Chapagain et al., 2006), it seems unrealistic as a solution for the regions most urgently in need in the face of the global inequalities in power and capital that also 
limit food distribution (cf. Meek and Meek, 2009). On the other hand, export of virtual water from dry and mountainfed regions such as the Mediterranean, South America and Asia should be reassessed very critically. In some regions, it might however be possible to reduce water stress by improving water quality. In the Andes, for instance, significant economic activity takes place at high altitude, including very polluting industries such as mining. These areas are headwaters of large river systems that are intensively sourced in the drier coastal areas. Combined with a lack of local regulation, pollution of these rivers may make them unsuitable for extraction or pose health risks.

From the present point of view, the most promising option to re-balance supply and demand seems to be reducing demand (see Molden, 2007) which, as opposed to improvements in infrastructure in order to increase water supply, is generally much cheaper and avoids associated undesirable indirect effects such as ecosystem disruption and loss of arable land. For regions with low or medium economic development and high dependence on irrigated agriculture, reducing demand may be achieved by implementing more efficient water-saving irrigation techniques. For Pakistan, for example, the World Bank (2005) notes the "hopeful fact" that there is much scope for increasing productivity given the low crop yields (e.g. wheat yield per unit of water in Pakistan is 50\% of that in the Colorado River Basin). Where economic development is already high, reduction of demand can be achieved relatively easily by technological advances that improve irrigation efficiency (see e.g. FAO, 2002), reuse of treated waste water, regulatory approaches (e.g. prohibit irrigation of certain crops and excessive private water use during drought periods) and general conservation measures (e.g. campaigns for reduced household water use). It should however be borne in mind that population dynamics and economic development will significantly increase water demand in some regions (see e.g. Lins and Stakhiv, 1998; Koutsoyiannis et al., 2009), such as the Middle East (Bou-Zeid and El-Fadel, 2002) or the densely populated catchments that originate in the Hindu Kush-Karakoram-Himalaya (WWAP, 2009).

\section{Research and monitoring needs}

In identifying research needs with a view to water resources management, we should prioritise issues that have the highest potential for improving runoff projections. In our view, the highest priority is to improve projections of all types of precipitation, not only regarding amounts, but also spatial distribution, resolution and temporal variability. Considering that the GCMs represented in the IPCC AR4 are not even able to provide certainty about the sign of projected changes in many regions, problems with all other components of the hydrological cycle are likely to be dwarfed by these uncertainties. Further issues of relevance concern better estimation of snow water equivalent, more detailed data on soil properties and better monitoring and modelling of evapotranspiration. In the regions that were studied as a basis for this article (see Sect. 2), aforementioned priority ranking is almost universal, with only a few minor differences that apply to the relative position of the lower priorities. These and a few more research priorities in process knowledge will be discussed below.

\subsection{Research priorities}

\subsubsection{Improving precipitation projections}

Thinking about improvements in precipitation projections quickly brings us to climatological downscaling and its particular advantages in mountainous regions where the accurate representation of spatio-temporal variability of precipitation is a huge challenge. GCMs are run at a very coarse resolution $(\sim 300 \mathrm{~km} \times 300 \mathrm{~km}$ grid cells $)$ and are therefore not able to reproduce high-resolution features and mountain-specific effects like orographic forcing and rain-shadowing. To model such mountain-induced circulation patterns it is necessary to run limited-area models or to dynamically downscale GCMs using Regional Climate Models (RCMs). Since running RCMs is extremely computationally intensive, however, statistical downscaling (SD) is frequently used as an alternative. Statistical downscaling normally fits an empirical relationship between local observations and regional climate features (e.g. circulation patterns, pressure fields etc.) using historic data and then assumes that this relationship can be used to estimate future changes in local climate from the same regional features modelled using global or regional climate models. Although the results of SD are not based on physical process modelling, they often provide equally reliable results (Fowler et al., 2007). SD has, for instance, great potential in the Andes where temporal precipitation variability is highly correlated with large-scale upper air flow which can be adequately simulated in GCMs (Garreaud et al., 2003). Finding the most appropriate downscaling method is not always straightforward, and the choice depends on the temporal and spatial scale in focus. It should however be borne in mind that the choice of the driving GCM generally introduces the largest uncertainty and, together with the choice of emission scenario, is even more decisive for the results than the downscaling method used (Fowler et al., 2007). Therefore, a probabilistic approach should be pursued, using multi-model ensembles of GCMs and downscaling methods to allow the largest uncertainties in future projections of climate change to be explored adequately.

In the context of mountain water resources, with their often pronounced seasonality, air temperature also has an important impact on runoff. Compared to precipitation, the downscaling of temperature is however much more straightforward. The accurate representation of precipitation is, at first glance, not as important for high elevation basins where 
the runoff seasonality is controlled by snow and ice melt and, hence, predominantly by air temperature. However, since much of the summer runoff is provided by the melting of the previous winter snowfall, reliable projections are required for both air temperature and the temporal and spatial distribution of precipitation for assessing the future behaviour of glaciers and their role in providing meltwater during summer months. For example, it has recently been suggested that glaciers in the Karakoram are showing a tendency of mass increase that is in opposition to the trend of rapidly retreating glaciers in the Himalaya (Hewitt, 2005). This may have been caused by a general increase in winter precipitation (as snow) at the confluence of the Westerlies and the southwest Asian Monsoon (Archer and Fowler, 2004). In spite of rising temperatures, altitudes that are still located above the snowline may receive more winter snowfall, leading to glacier mass accumulation (Bishop et al., 2008). Alternatively, mass increase may be a result of lower summer temperatures related to increased cloudiness, reducing the amount of melt from snow and ice and reducing the concurrent summer flow in the high tributaries of the Indus (Fowler and Archer, 2006).

Overall, much research on downscaling is still needed for the Tropics and the developing world. These regions have been rather neglected despite the importance of more reliable information on climate risk for development and adaptation planning where economic growth is already severely hampered by climate variability and change (Fowler and Wilby, 2007). Research should also continue beyond examining downscaling in the context of climate change to assess the impacts on hydrology and provide advice for stakeholders and managers for dealing with water adaptation to climate change (Fowler and Wilby, 2007). Following Koutsoyiannis et al. (2009), we argue that the uncertainties related to predicting the future availability of water resources requires a more intensive dialogue between climatologists and hydrologists.

\subsubsection{Snow water equivalent}

Seasonal snow has a considerable effect on the water balance of many rivers (cf. Barnett et al., 2005; Adam et al., 2009). To date, however, the snowpack is represented only in strongly simplified manner in macro-scale hydrological models (Widén-Nilsson et al., 2009), and more detailed representations are restricted to specialised models that operate at the local scale (e.g. Lehning et al., 2006). Snow-covered area is usually accounted for by either modelling the snowpack, such as in the popular HBV (Hydrologiska Byråns Vattenbalansavdelning) model (Bergström, 1976) or using observations of snow-cover, as applied in the Snowmelt-Runoff Modell (SRM) by Martinec (1975). The main strategies for estimating snowmelt rates include either using conceptual and relatively simple temperature-index models or more physically-based and complex energy-balance models; the latter benefit from more accurate process descriptions but in turn require far more detailed data (Ferguson, 1999), especially when forest areas are concerned (Rutter at al., 2009). An exhaustive overview of snowmelt runoff modelling is available from DeWalle and Rango (2008).

For better estimation of possible future shifts in runoff seasonality, more reliable estimates of Snow Water Equivalent (SWE) and its spatial distribution are required as a basis for improving our models or at least for calibrating the snow sub-model more rigorously. This improvement mainly calls for better observation techniques and a widespread use of them in monitoring. Besides ground-based point samples (e.g. from snow pillows), space and airborne estimates are of particular interest because they are more representative of an area:

- The advanced passive microwave scanning radiometer on board of the National Aeronautics and Space Administration (NASA) Earth Observing System (EOS) Aqua satellite currently provides global spaceborne estimates of SWE. The scattering effects of snow cover are related empirically to snow-cover depth and water content based upon field measurements. Daily, 5 day maximum and monthly mean SWE estimates are available at a spatial resolution of $25 \mathrm{~km}$ from 19 June 2002 to the present. Sources of error include variations in snow crystal size, wet snow discrimination and snow mapping in densely forested areas (NASA, 2006), and the accuracy of snow detection in mountainous terrain is still limited by the relatively coarse spatial resolution (Lemke et al., 2007). More detailed SWE data might be retrieved from the COld REgions Hydrology High-resolution Observatory (CoReH2O). The observatory is a candidate mission for the European Space Agency (ESA) Earth Explorer Programme due for launch in the first half of the present decade (ESA, 2008). CoReH2O utilises twin frequency Synthetic Aperture Radars (SARs) with an emphasis on, among other things, parameterisation of snow and ice processes as represented in hydrological and numerical weather forecasting models as well as climate research applications and validation of hydrological and coupled landatmosphere models (Rott et al., 2008).

- SWE estimation at regional scale is possible via airborne gamma radiation sensing as developed and maintained in the United States by the National Oceanic and Atmospheric Administration (NOAA) National Operational Hydrologic Remote Sensing Center (NOHRSC). The method uses the attenuation of the terrestrial radiation signal by water mass and, given a realistic estimate of soil moisture in the upper $20 \mathrm{~cm}$ (eight inches) of soil, allows determination of total above ground moisture, i.e. SWE (Carroll, 2001). Flight lines are approximately $16.1 \mathrm{~km}$ (10 miles) long and $1.6 \mathrm{~km}(1 \mathrm{mile})$ wide, while the aircraft flies at about $150 \mathrm{~m}$ (500 feet) 
above the ground. The NOHRSC uses SWE data from these surveys operationally, for example, for issuing water supply and flood forecasts.

A comprehensive overview of snow measurement techniques and the associated problems has recently been presented by Lundberg et al. (2010). For measurement of SWE, the authors mention snow pillows and pressure sensors as suitable direct techniques and highlight active gamma radiation attenuation, cosmic radiation attenuation and ground-penetrating radar as well-suited indirect techniques, although the latter are dependent on direct measurements for validation.

The effort of SWE estimation can be reduced considerably if snow depth is used as a surrogate. This method requires a reliable model for snow density, such as that proposed recently by Jonas et al. (2009) for the Swiss Alps as a function of season, snow depth, site altitude, and site location. The development of such a model requires extensive series of measured snow densities and snow depths: Jonas et al. (2009) used more than 11000 such measurements, taken at 37 sites over the past 50 years. The snow depth data necessary for applying such a method, in turn, could even be measured with inexpensive temperature sensors (Reusser and Zehe, 2010).

Snow distribution, in contrast, can already be estimated now from remote sensing. In addition, advanced image processing algorithms are available to estimate the fraction of snow cover within individual pixels (Foppa et al., 2007), which helps to characterise better the discontinuous and heterogeneous distribution of snow cover in mountainous regions. The marked topography of mountain areas, however, introduces additional challenges to remote sensing such as aspect-dependent illumination and reflectance differences, topographic shadowing, geometric distortion as well a more pronounced lack of ground control data, and challenges common to remote sensing in all environments (e.g. haze and clouds) persist (Weiss and Walsh, 2009).

\subsubsection{Soil parameters}

The lack of relevant soil parameters at an adequate resolution is a universal problem in hydrological modelling. Information on soil depth, porosity, wilting point, field capacity and hydraulic conductivity is frequently used to parameterise conceptual models, and insufficient accuracy of this information results in increased uncertainty. Soil properties are usually mapped poorly and at a coarse resolution only, and there will likely be no major improvement in the near future, owing to the high cost and low scientific recognition of extensive field campaigns. The problem is amplified in mountain regions with their high heterogeneity of conditions for pedogenesis. Further development and implementation is also required in interpretation of existing soil maps with view to hydrological processes (e.g. dominant runoff processes, see Schmocker-Fackel et al., 2007). Hydrological and climatological modelling would also draw great benefit from improved, coordinated and more extensive in situ soil moisture observations that could be used, among other things, for verifying the models' soil modules. At the global scale, the ESA Soil Moisture and Ocean Salinity Mission (SMOS) has great potential for providing comprehensive data. SMOS, launched in November 2009 and operational since May 2010, operates at the L-band and is designed to provide a global image of surface soil moisture every three days, at a resolution of 35 to $50 \mathrm{~km}$ and with a penetration depth of 3 to $5 \mathrm{~cm}$ (Kerr et al., 2000; ESA, 2009).

The situation is a little better for land cover which can be derived with reasonable accuracy and effort from remote sensing information. Aerial photography, which provides better data at present, is very costly.

\subsubsection{Evapotranspiration and sublimation}

Considerable difficulties apply to evapotranspiration (ET) and its behaviour under a changing climate. On the one hand, observed values of ET are usually very scarce, especially in dry climates where direct measurements are also quite difficult. On the other hand, the present state of ET is not necessarily meaningful for the future since changes in processes could exert significant influence. The suppression of plant transpiration due to reduced stomatal aperture with increasing $\mathrm{CO}_{2}$ levels (see e.g. Gedney et al., 2006a; Betts et al., 2007) could, for example, counteract the general trend for higher potential ET at the global level. On the basis of in situ measurements for deciduous trees, Leuzinger and Körner (2007 and 2010) found that reduced stomatal conductance under elevated $\mathrm{CO}_{2}$ results in a decrease of annual ET of up to $10 \%$ and hence an increase in soil moisture, provided that all other factors remain constant. Modelling a series of more than 100 years, the authors also found that the associated increase in runoff will be very small $(<3 \%$, probably even smaller for other ecosystems and larger catchments) and that the key driver of this increased runoff was the day-today rainfall pattern. Grassland on Calcare and on high alpine stands shows a reduction of ET with elevated $\mathrm{CO}_{2}$ by 3 to $7 \%$, depending on grassland type (Stocker et al., 1997; Inauen et al., 2010). For coniferous trees, in contrast, similar effects have not been observed.

Better representation of soil-plant-atmosphere exchange in climate models and improved treatment of the energy budget are therefore important tasks for research. The magnitude of changes in ET and their impact on hydrology depend very much on the specific environment. Moreover, possible changes in land use may also be important for ET, no matter whether they are caused by climate change, migration, economic development, or altered land use practice. In the Pyrenees, a significant increase in ET is expected due to the growth of vegetated area, caused by a very likely continuation of the abandonment of agricultural land and grazing activities as well as a rise of the tree line as a consequence of warmer temperature and a decrease of livestock in 
the subalpine belt (López-Moreno et al., 2008). In regions where shrub and forest growth are dominant, the impact of increased ET may even outweigh other climate-change related effects.

While sublimation can be an important process to consider in most snow- or glacier-covered mountain regions (e.g. Hood et al., 1999), it is especially relevant in arid and semiarid mountain regions such as the subtropical Andes or the High Atlas where climates characterised by low humidity and high wind speeds combine to produce high sublimation rates (e.g. Ginot et al., 2001; Schulz and de Jong, 2004). Reduced cloudiness and the resulting negative long-wave radiation balance, in conjunction with weak vertical air temperature gradients and a large vapour pressure gradient generally result in enhanced sublimation (Wagnon et al., 1999a, b and 2001; Kaser et al., 2005; Sicart et al., 2005). Since sublimation is 8.5 times less energy efficient than melting, high sublimation rates lead to an overall reduction in mass turnover (reduced melt rates) and hence result in lower river runoff from glaciated or snow-covered catchments. In fact studies in the tropical and subtropical Andes have documented that the enhanced runoff observed in glaciated catchments during the wet season is not the result of an increased energy input, which remains quite constant throughout the year, but is caused by the seasonally varying partitioning of the available energy into melt and sublimation (Wagnon et al., 1999a). Estimates of total sublimation rates vary but range up to $44 \%$ of total snow ablation in the High Atlas (Schulz and de Jong, 2004) while studies in the arid Andes have shown that more than $50 \%$ of total annual snowfall is subsequently removed by sublimation (Ginot et al., 2006). How sublimation will affect river discharge in these catchments in climate change scenarios is an open question, but given that glacier extent and the seasonal extent and duration of snow cover will decrease in a warmer environment, the overall impact of sublimation on freshwater resources will likely become less relevant in the future (see Corripio et al., 2007).

\subsubsection{Groundwater}

Groundwater recharge at the mountain front can be important for replenishment of aquifers (Manning and Solomon, 2005), and is even its predominant source in many basins in arid and semiarid climates (Wilson and Guan, 2004). Recharge of the Atacama Desert aquifer, for example, has been shown to be fed mainly from rainfall and snowfall in the high Andes (e.g. Houston et al., 2002), and Döll (2009) found that human vulnerability to a climate change induced decrease of renewable groundwater resources is very high for the central Andes. Groundwater in the lower Indus plains is significantly recharged by leakage from irrigation canals fed from the Indus River and therefore also dependent on mountain sources (Archer et al, 2010). It should also be borne in mind that anticipated reductions in summer low flows in snow-dominated basins (see Sect. 3.1.3) and increasing pre- cipitation variability may lead to an increase in demand for groundwater to compensate for changes in availability of surface water (Kundzewicz et al., 2007).

To provide a better overall picture, it is crucial to improve process knowledge about groundwater flows or at least quantitative data about the extent and renewal rate of large aquifers. Detailed knowledge that is missing today concerns groundwater interaction with surface water as well as the dependence of groundwater on natural vegetation, land management and abstraction. This also concerns mechanisms, influences and rates of recharge at the mountain front. A better understanding of the relevant processes such as partitioning of water between interflow and deep percolation and flow paths through mountain blocks (see Wilson and Guan, 2004 for details) would help to improve assessment of climate and land use change impacts on groundwater quantity and quality (see e.g. Döll, 2009; Goderniaux et al., 2009; Kundzewicz and Döll, 2009), and it might also be an important step towards exploring active management of groundwater resources (such as artificial groundwater recharge). The improvements in understanding necessary also concern the space-time distribution of mountain precipitation and ET already discussed in Sects. 4.1.1 and 4.1.4.

\subsubsection{Enhanced warming and feedback mechanisms}

We conclude our presentation of research priorities with remarks on the enhanced warming that is assumed for high elevations as a consequence of energy budget and related feedback mechanisms in mountain areas. The issue of enhanced warming is vital for determining speed and extent of potential changes in seasonal to multidecadal water storage in the form of snow and ice (Messerli et al., 2004).

There are two relevant feedback mechanisms. First, depletion of snow- and ice-covered areas reduces surface albedo and thus leads to an increased absorption of short-wave radiation. Owing to its close connection to the seasonal snowpack, this effect is strongest in winter and spring of the mid latitudes (Giorgi et al., 1997) and has considerable influence on temperature trends in mid elevations that are located near the annual $0^{\circ} \mathrm{C}$ isotherm (Pepin and Lundquist, 2008). Second, decreasing cloud cover at high elevations increases incoming solar radiation, forming a cloud-radiation feedback cycle. This feedback was discussed for the Tibetan Plateau by Duan and Wu (2006) and Liu et al. (2009) and is also likely to have occurred in the European Alps (Auer et al., 2007). In addition to these feedbacks, mountains are more directly exposed to the middle troposphere where the enhanced hydrologic cycle will augment the release of latent heat, leading to enhanced warming in high mountain regions, primarily in the tropical latitudes (Bradley et al., 2004 and 2006).

Closer examination however reveals that there is no definitive consensus about enhanced warming at high elevations and the physical mechanisms involved. While numerous studies have found clear evidence of enhanced warming in 
20th century observations (Beniston and Rebetez, 1996; Diaz and Bradley, 1997; Shresta et al., 1999; Liu and Chen, 2000; Diaz et al., 2003; Diaz and Eischeid, 2007) or numerical experiments with climate change scenarios (Giorgi et al., 1997; Fyfe and Flato, 1999; Snyder et al., 2002; Chen et al., 2003; Bradley et al., 2004; Urrutia and Vuille, 2009) or both (Liu et al., 2009), other studies have not led to uniform confirmation (Nogués-Bravo et al., 2007), were inconclusive (Pepin and Seidel, 2005) or even contradictory (Vuille and Bradley, 2000). Contradictory results have even been found for the same region. The European Alps are such an example: Beniston and Rebetez (1996) examined 15 years of temperature minima observations across Switzerland and found a very significant altitudinal dependency of warm and cold anomalies, with a positive altitude gradient for warm winters and a reverse anomaly for cold winters. Auer et al. (2007), in contrast, did not detect enhanced warming (or cooling, for that matter) in their comprehensive study which encompasses the entire Greater Alpine Region and features temperature records that extend back as far as to 1760 . They rather found that the entire alpine region has experienced a warming twice as high as the global or Northern Hemispheric average since the late 19th century, and the data suggest that this was most likely caused by reduced cloudiness. Further contradictions have been pointed out for the Rocky Mountains (Pepin and Losleben, 2002; Diaz and Eischeid, 2007) and the Tibetan Plateau (Liu and Chen, 2000; You et al., 2008).

It is concluded that detection of altitude gradients in warming is not straight-forward as such gradients depend on latitude, region, scale, timeframe and methods and are disturbed by local-scale effects such as the high variability of temperatures as well as gradually occurring changes in land cover and patterns of aerosol emission and transport (see discussion by Liu et al., 2009). Further bias is introduced because many high-elevation climate gauging sites are located in valleys, mixing up the effects of topography and elevation (Pepin and Seidel, 2005). Pepin and Lundquist (2008) argue that high elevation measurements are still of high value for early detection of increasing temperatures, although maybe not because of enhanced warming but rather because summit locations are more directly influenced by the free troposphere and lack the surface complexities and anthropogenic disturbances of lower elevations which cause significant "noise" in temperature trends. With the help of principal component analysis, Böhm et al. (2001) found that the data from remote places on mountain peaks in high-level alpine areas may well represent "climatic background information" right in the centre of densely populated Europe.

In view of the large uncertainties and the importance for determining the vulnerability of mountain areas towards a changing climate, a more detailed representation of energy budgets and feedback mechanisms in models is urgently needed.

\subsection{Importance of environmental monitoring}

Bearing in mind the research needs described above, we should not forget that environmental monitoring is an indispensable prerequisite for improving our understanding of all components of the hydrological cycle (Kundzewicz et al., 2008). This is especially true for high altitudes where large temporal variability and spatial heterogeneity of processes call for even more extensive and long-term monitoring efforts.

\subsubsection{Variables with high priority}

One of the most important variables to be gauged in mountainous areas is precipitation. The corresponding networks are usually biased towards lower elevations (see following Sect. 4.2.2), and the combination of considerable measurement errors (mainly associated with wind, especially with regard to snow; see Goodison et al., 1998; Nespor and Sevruk, 1999; Yang, 1999) and local-scale orographic effects further decrease the reliability of present estimates (Neff, 1977; Legates and DeLiberty, 1993; Sevruk, 1997; Sevruk et al., 1998; Adam et al., 2006). Remote sensing or weather radar, although valuable for complementing precipitation estimates, are not likely to become reliable surrogates in the near future since conversion of sensor data remains difficult. Calibration of such techniques will inherently remain subject to the availability of steady and reliable ground truth gauge observations. In addition, weather radar data show significant problems in mountain regions, such as beam shielding, strong ground clutter, underestimation and non-detection of precipitation and difficult operating conditions (Young et al., 1999; Germann et al., 2006).

Another important component subject to significant lack of data is snow. Although it has been possible to improve the availability of snow cover data using space-borne sensors and advanced processing techniques (e.g. Dozier and Painter, 2004; Parajka and Blöschl, 2005; Foppa et al., 2007; Hall and Riggs, 2007; Dozier et al., 2008; Hall et al., 2010), more detailed information is still required on snow water equivalent (SWE). More extensive field monitoring of SWE would be of high value for validating hydrological models and could be used for developing and testing independent SWE reconstruction models on the basis of remote sensing information as demonstrated by Molotch (2009) (see also Sect. 4.1.2). Due to the current lack of data, our understanding of the sensitivity of snow melt and associated changes in runoff to warming and changes in precipitation is still very limited (Stewart, 2009).

Significant data gaps apply to glacier mass balance, which is central for evaluating corresponding models. Glacier mass balance data may also serve to constrain the parameters of hydrological models in remote areas where data on runoff are limited or not available at all (Konz and Seibert, 2010; Finger et al., 2011). Changes in mass balance are however 
much more difficult to determine than changes in glacier length. Due to the logistical challenges involved, the sample of glaciers with mass balance monitoring is biased towards the morphologically simple and more accessible glaciers, as well as towards the Northern Hemisphere and in particular Europe, and only few records date back to the mid 20th century (see WGMS, 2009 and Zemp et al., 2009). In view of this, the work of scientific glacier monitoring networks such as the World Glacier Monitoring Service (WGMS) (Zemp et al., 2008) is highly important for collecting and disseminating standardised data on glacier changes worldwide.

Large gaps are also present in streamflow measurement, especially as regards uninfluenced records from high altitudes that capture seasonal melt of snow and ice. In its function as the integrative hydrological response from a catchment, streamflow is obviously central for enabling trend studies (e.g. Gedney et al., 2006b; Peel and McMahon, 2006; Körner et al., 2007) as well as for verifying and improving models. Even limited streamflow measurements can effectively help to constrain model predictions. Seibert and Beven (2009) have demonstrated this for a set of catchments in Sweden, finding that the amount of snow accumulation during winter had a decisive influence on model efficiency. They concluded that much more research is necessary for identifying the most promising measurement strategies. Today, monitoring data are available for only two thirds of the actively drained land surface area (Dai and Trenberth, 2002), and these records vary widely in length, frequently contain gaps and are, in addition, subject to biases from diversions and reservoir storage. The highly problematic bias towards low altitudes will be discussed in the following Sect. 4.2.2. Remotely sensed data might serve to reduce error and uncertainty in hydrological models for ungauged basins but is no substitute for a dense in situ gauge network (Neal et al., 2009).

While the importance of gauging further variables such as groundwater level and water quality or ET was already highlighted in the preceding section, water consumption also needs better quantification. Archer et al. (2010) note the difficulty of effective management of the Indus Basin Irrigation System in the absence of a licensing system for groundwater, inadequate measurement of distributary offtakes, high leakage losses from irrigation channels and pipelines to groundwater and illegal abstractions. Such unregulated water transfers, which are not uncommon, may constitute a high percentage of total consumption.

\subsubsection{Representativeness for high altitudes}

As indicated in the preceding section, variability and heterogeneity of processes in mountain areas are faced with a lack of instrumental records for high altitudes. This will be illustrated below in more detail for two key hydrometeorological variables, namely runoff and precipitation.

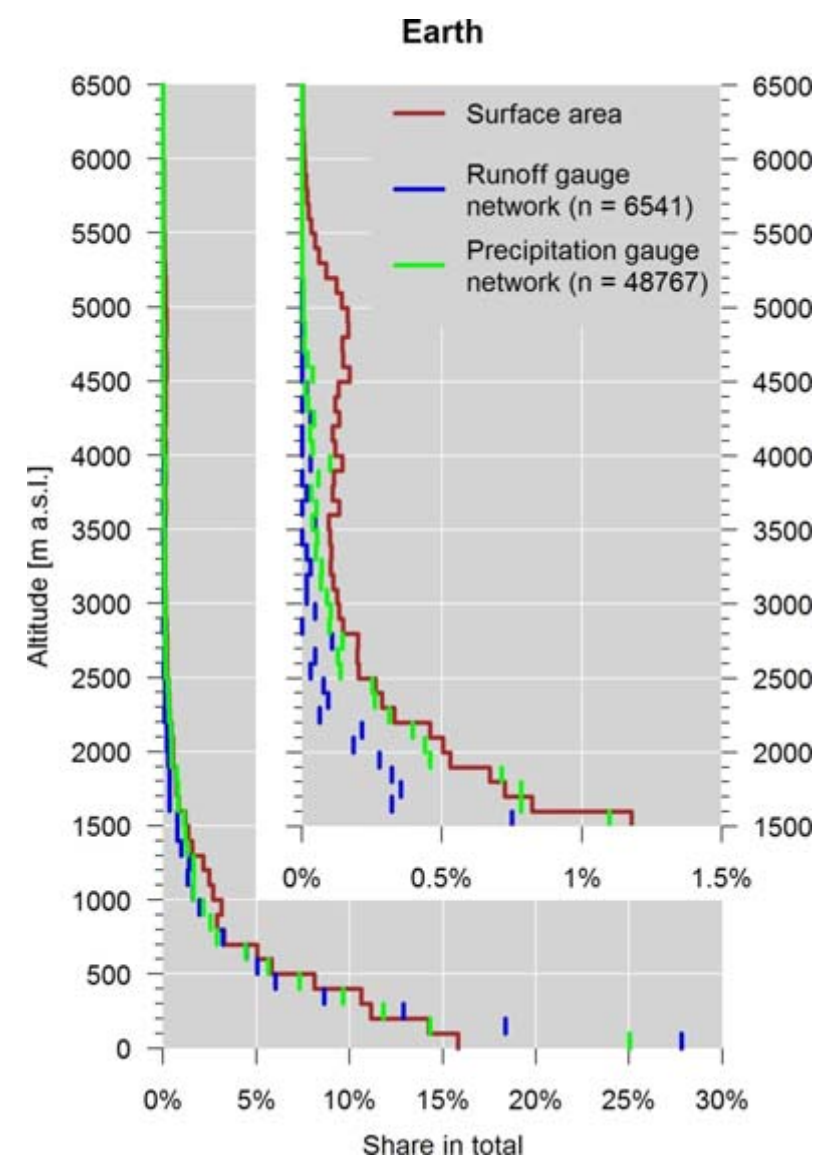

Fig. 3. Altitudinal distribution of global runoff stations represented in the GRDC archive and global precipitation station network represented in the GPCC archive compared to global hypsography of the land surface area (without Greenland and Antarctica). The inset shows a magnification for altitudes above $1500 \mathrm{~m}$ a.s.l.

Figure 3 characterises the global runoff and precipitation observation network by showing the altitudinal distribution of runoff gauge data accessible via the Global Runoff Data Centre (GRDC) (GRDC, 2009) and precipitation gauge data available from the Global Precipitation Climatology Centre (GPCC) (GPCC, 2010). The two archives are among the largest and most respected sources of runoff and precipitation data on the global scale. Station altitudes, although reported for many stations in both catalogues, cannot always be considered reliable and were derived from the $0.5^{\prime} \times 0.5^{\prime}$ resolution global digital elevation model GTOPO 30 (USGS, 1996) with help of the reported station location. Stations were included in the analysis on condition that they provide data in daily resolution for at least 10 years, and that their altitude could be determined from GTOPO 30, which was the case for 6541 GRDC stations and 48841 GPCC stations. The altitudinal distribution of the runoff and precipitation observation network is compared with the hypsography of the global land surface area (without Greenland and Antarctica) 


\section{Rain gauges by continent}

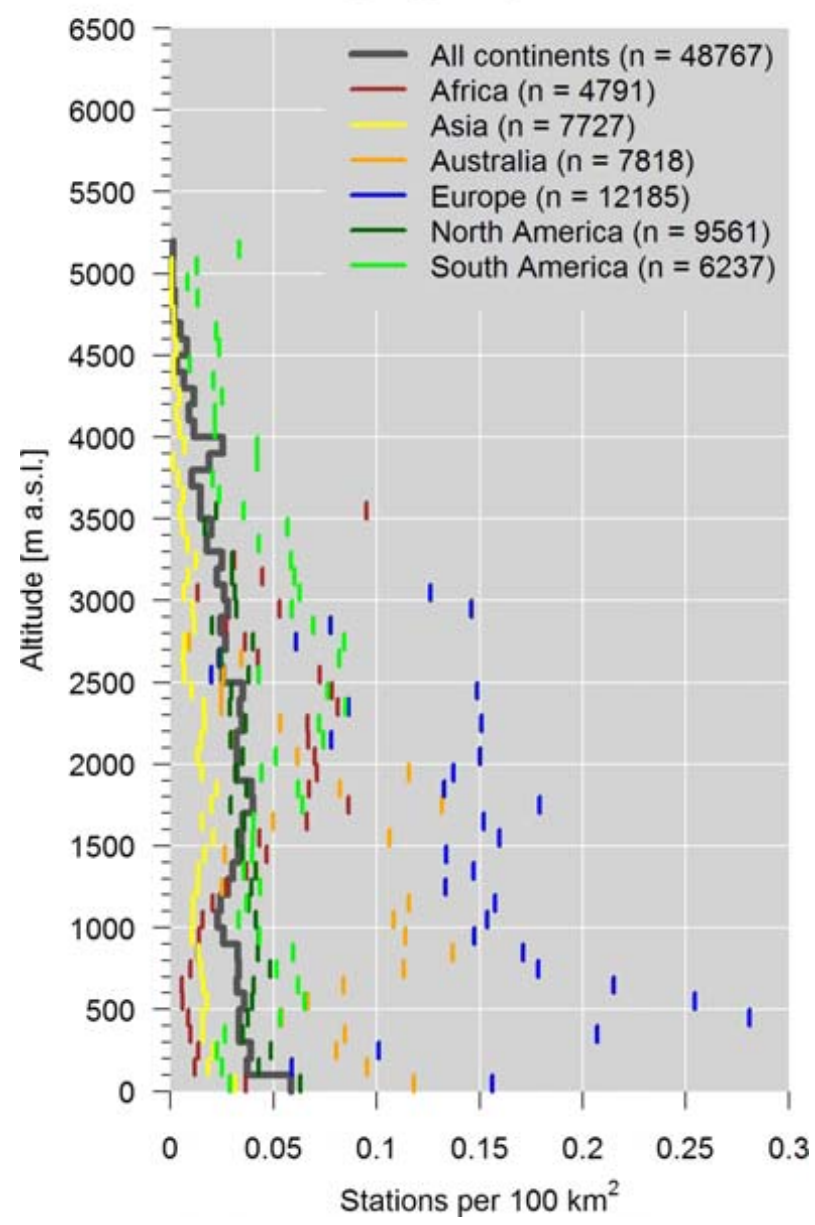

Fig. 4. Density of precipitation stations represented in the GPCC archive per continent and altitudinal range.

which was also derived from GTOPO 30. For the GRDC runoff station archive, the majority of stations are located below $300 \mathrm{~m}$ a.s.l., and under-representativity is observed for altitudes above $1500 \mathrm{~m}$ a.s.l. It should be noted however that the runoff gauge location analysed refers to the basin outlet, while the respective runoff measurements apparently integrate information from the entire basin which also spans to higher altitudes. Representativeness of the GPCC precipitation archive is surprisingly good when looking at the entire altitude range, with only altitudes below $100 \mathrm{~m}$ a.s.l. being overrepresented. The inset of Fig. 3 shows, however, that altitudes above $2500 \mathrm{~m}$ a.s.1. are slightly underrepresented, and those above $3500 \mathrm{~m}$ a.s.l. increasingly underrepresented.

The characteristics of the precipitation gauge network are broken down into network density per continent in Fig. 4. Europe clearly has the densest network ( 0.13 stations per $100 \mathrm{~km}^{2} / 791 \mathrm{~km}^{2}$ per station), although with a marked centroid around $500 \mathrm{ma.s.l}$. and a subsequent decrease with higher altitudes. The lowest density is present for Asia (0.02 stations per $100 \mathrm{~km}^{2} / 5633 \mathrm{~km}^{2}$ per station), which exhibits even lower values above $2500 \mathrm{~m}$ a.s.1. (0.004 stations per $100 \mathrm{~km}^{2} / 26692 \mathrm{~km}^{2}$ per station). Africa and South America possess their highest densities at intermediate and high altitudes (1600-2600 m a.s.1. and 1700-3500 m a.s.1., respectively), although it should be noted that the densities are clearly lower than for Europe and the absolute number of high altitude stations is very low for Africa. North America follows the global average with a relatively steady decrease of network density with altitude. High and very high altitudes are therefore mainly represented by the 292 South American stations that are located above $3000 \mathrm{~m}$ a.s.l. These make up $73 \%$ of the global network above this altitude, although South America covers only $23 \%$ of global land surface area above $3000 \mathrm{~m}$ a.s.l. outside of Greenland and Antarctica. Note that the WMO (1994) recommendation of 0.4 stations per $100 \mathrm{~km}^{2}\left(250 \mathrm{~km}^{2}\right.$ area or less per station) for mountainous areas is clearly missed in this continental analysis. WMO recommendations for plains and hills $(0.17$ stations per $\left.100 \mathrm{~km}^{2}\right)$ as well as for coastal areas $(0.11 \mathrm{sta}-$ tions per $100 \mathrm{~km}^{2}$ ) are only met in Europe and Australia. A similar analysis for runoff was not made because the sample of stations per continent was considered to be too small, with a total of only 70 stations above $2000 \mathrm{~m}$ a.s.l. representing an area of $7.7 \times 10^{6} \mathrm{~km}^{2}$.

This analysis is by no means intended to criticise the highly important work of hydrometeorological surveys and even less that of data collection and distribution centres like GRDC and GPCC. They rather illustrate that improvement of monitoring at high altitudes is indeed an important and necessary task if we want to enhance the data base for understanding processes in mountain areas. In particular, Asia should be a priority because of its extensive high-elevation areas that are inadequately monitored and at the same time highly significant for downstream hydrology and water resources (cf. Sect. 3.1.1). Moreover, higher priority should be given to fully equipped meteorological stations that are of high importance for determining the energy balance of highaltitude sites (cf. Sect. 4.1.6).

The global and continental overview presented above is, of course, a simplification. To show that monitoring of high altitudes is not sufficient even at the local and regional scale, a similar analysis was performed for Switzerland, representative of a region characterised by marked relief and at the same time possessing one of the world's densest runoff and precipitation observation networks (Schmidli et al., 2001; Weingartner and Pearson, 2001). Figure 5 compares the hypsographic curve derived from the Swiss Digital Elevation Model at a resolution of $0.1 \times 0.1 \mathrm{~km}^{2}$ (FSO, 2003) with the altitudinal distribution of 568 runoff gauges (FOEN, 2009) and 608 precipitation gauges (MeteoSwiss, 2005) which have recorded data for at least 10 years and at least in daily resolution. The gauging network is generally very representative for intermediate altitudes, the most frequent altitude band of 400-500 ma.s.l. is clearly overrepresented. Above 
an altitude of $1500 \mathrm{~m}$ a.s.l., where snow and ice melt processes are dominant in the runoff regime (Viviroli and Weingartner, 2004), 37\% of total surface area is however represented by only $7 \%$ of the runoff and $10 \%$ of the precipitation gauge networks. The overall density of the runoff observation network is 1.37 stations per $100 \mathrm{~km}^{2}$ which is well above the minimum density of 0.1 stations per $100 \mathrm{~km}^{2}\left(1000 \mathrm{~km}^{2}\right.$ area or less per station) recommended by WMO (1994) for mountainous regions. The recommended density is, however, only met for altitudes of up to about $2100 \mathrm{~m}$ a.s.l. This seems acceptable when considering that a dense network would not make sense for much higher altitudes where snow and glacier cover dominate. For precipitation, the WMO recommendation of 0.4 stations per $100 \mathrm{~km}^{2}$ for mountainous regions is met in Switzerland on average with 1.47 stations per $100 \mathrm{~km}^{2}$. The recommendation is still closely met on average for the entire territory above $1500 \mathrm{~m}$ a.s.l. with 0.38 stations per $100 \mathrm{~km}^{2}$, but is missed for altitudes above 2000 m a.s.l. which still make up $24 \%$ of the country's total area.

\subsubsection{The way forward}

The general lack of observational data is detrimental in mountains of the arid and semi-arid zones of the Tropics, Subtropics and Mediterranean region where dependence on mountain runoff in the adjacent lowlands is highest. In spite of this, the sparse hydrological, climatological and glaciological monitoring networks that exist today face a tendency for reduction in numbers due to the high operating cost of measuring stations in remote mountain areas with their harsh environmental conditions. This tendency must be reversed. Furthermore, public access to measured data must be improved, above all in regions of frequent water scarcity where the dissemination of data is often prohibited for political reasons, especially in South Asia.

How can the tendency of shrinking observation networks be reversed? There is no way around increasing funding for monitoring and building research capacities, and local policy makers have a large responsibility here. However, governments are increasingly aware of this problem and availability of scientific resources is improving, particularly in emerging economies such as Peru and Colombia. At the same time, emerging technologies and techniques such as cheap and resilient sensor networks facilitate this process. A promising approach is also the inclusion of local stakeholders in the monitoring and modelling process, which fosters ownership and knowledge dissemination and at the same time decreases costs and improves quality (e.g. Roa García and Brown, 2009; Voinov and Bousquet, 2010). An interesting example is found in the Andes where participatory environmental monitoring is actively being explored as an important component of regional development. Data on precipitation and river flow are collected by farmers who are then able to

\section{Switzerland}

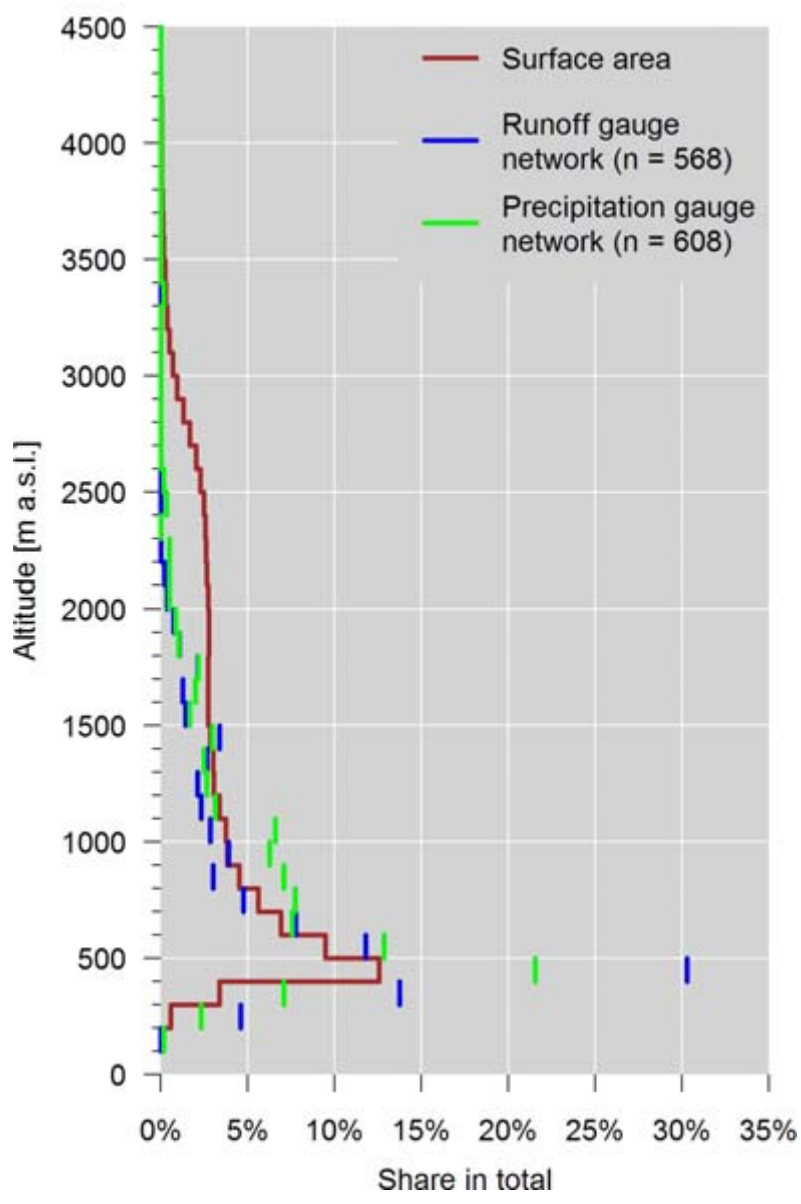

Fig. 5. Altitudinal distribution of the runoff and precipitation gauge networks in Switzerland compared to hypsography.

improve irrigation schedules and water supply systems. The data collected are also essential for negotiating compensation for environmental services which can help diversify local incomes and make farmers more resilient to the anticipated effects of climate change (Buytaert et al., 2006). In order to secure continuity of observations in the long term and allow effective dissemination of data, however, it would be important to link such valuable initiatives into official networks at the regional or national level.

The utility of observational data can be greatly improved through internationally coordinated systems of observation networks that identify, obtain and make widely available comprehensive and reliable data records. The Global Climate Observing System (GCOS) (GCOS, 2007) is a fine example for such an initiative, although it might not adequately sample the higher elevation zones (Bradley et al., 2004). An initiative with more focus on mountains is CEOP-HP (Coordinated Energy and Water Cycle Observation Project High Elevations), which is dedicated to contributing to global 
climate and water cycle studies by providing rare but crucial information from elevations above $2500 \mathrm{~m}$ a.s.l. (Tartari et al., 2009).

Finally, remote sensing products bear considerable potential for improving our overview of variables that are important in water resources, such as precipitation, snow cover, soil moisture or even discharge. This kind of data might also be useful for constraining the parameters of climatological and hydrological models (Neal et al., 2009). Increasing the temporal and spatial resolution as well as the accuracy of such products, however, remains a challenging but necessary task. We already mentioned some landmark space missions in Sect. 4.2.1, where we also emphasised that remotely sensed data are no substitute for in situ observations since they rely on trustworthy "ground truth" measurements for continuous calibration and verification. Ground and space borne measurements are most valuable when used in a complementary manner, as was approached in the Available WAter REsource in mountain environment (AWARE) project for the European Alps (Rampini et al., 2008).

Despite these efforts, data scarcity will remain an issue for the foreseeable future, and therefore regionalisation and uncertainty estimation methods should be developed that deal with the specific conditions of data-scarce mountain environments (Buytaert and Beven, 2010), to help resilient decision making. Also, the limited availability of natural discharge series that hinders model calibration could be circumvented by innovative calibration techniques that use different observed hydrological signals and signatures rather than discharge only (Hingray et al., 2010). Development of new methods for hydrological predictions in ungauged or poorly gauged basins is also the focus of the IAHS (International Association of Hydrological Sciences) decade on Predictions in Ungauged Basins (PUB), which is expected to contribute significant knowledge by coordinating and stimulating the scientific community (Sivapalan et al., 2003). The challenges for PUB are, however, amplified in mountain regions due to the enormous spatial and temporal heterogeneity of environmental conditions. In addition, the "PUB paradox" - datarich basins are needed to improve our ability to make reliable predictions in data-scarce basins (Bonell et al., 2006) is particularly marked in mountain regions due to the scarcity of uninfluenced records from these environments.

\section{Recommendations to improve mountain water resources management}

On basis of the state of knowledge and the research needs identified, we will now provide some recommendations concerning how advancements in the management of mountain water resources under climate change can be achieved in the fields of research, management and policy, as well as through their interactions. Although some of our findings are certainly universal to water resources management under cli- mate change, many of the problems mentioned below are amplified in the highly vulnerable mountain regions.

\subsection{Recommendations for research}

\section{Research should improve the utility of science for water managers}

An important point for scientists is to "work harder at translating [...] science into practical measures that can be taken up and used at the point of delivery of adaptation" (Fowler and Wilby, 2007). One of the most crucial prerequisites for this is to understand that water managers require models that provide answers for the integrated system of water supply and demand, while scientists focus on models that advance process understanding. Managers are responsible for ensuring that water supplies are safe and reliable, and they have a tendency to be risk-adverse. As a result they are reluctant to accept untested innovations. Researchers must thus address uncertainties clearly by conducting vulnerability assessments followed by prioritising the risk.

\section{Research should develop scenarios that encompass changes in variability}

In order to address uncertainty, scientists often provide different scenario projections rather than make predictions. This provides a plausible range of possible future system states (Kundzewicz et al., 2009), on basis of which a range of management options can be identified that are most appropriate for each scenario, depending on risk priorisation. One very important research need is to focus more on changes in the variability in relation to the historic record than on average projected changes in temperature and precipitation: Management only becomes a problem when variability increases beyond the range of experience, i.e. when there are extreme events (e.g. floods, droughts, heat waves). Emphasis should be placed on developing scenarios on how the variability is likely to change. Indeed, since water managers are more interested in short-term impacts rather than in longrange climate change projections, the focus should be on capturing better seasonal and decadal variability within climate models and thus downscaled temperature and precipitation time series (Fowler and Wilby, 2007).

\section{Research should develop standardised regional scenarios}

Furthermore, it seems important to coordinate the use of climate projections at the regional scale (e.g. selection of emissions scenarios, scenario periods, GCMs and RCMs) in order to achieve results that are actually comparable to each other and thus of higher practical use. While the IPCC has taken on a coordinating role at the global scale, guidance at regional and even national scales should be improved. A good example is the Center for Climate Systems Modeling (C2SM) 
which aims at fostering and coordinating the development and application of climate models operating at various scales for the Swiss research community.

\section{Research should address the full set of drivers}

Another important research area is to incorporate explicitly land use changes which are taking place at the same time as climate change. In many places, especially in mountainous areas, these combined effects are more important than only looking at changes in rainfall and temperature, and some of these effects are likely synergistic or additive. Likewise, population growth and economic development should be considered in their defining role for future water resources.

\section{Research should engage in collaboration across disciplines}

The complexity of climate change issues in mountain areas makes it nearly impossible for an individual researcher to represent all of the relevant areas of expertise. This strongly calls for scientists to engage in interdisciplinary research and to commit to acting on advisory boards and similar scientific bodies.

\section{Research should examine suites of adaptive measures}

Research should also focus on a range of adaptive measures rather than single options because it is becoming clearly evident that no single option will be sufficient to deal with the integrated effects of climate and land use change in a watershed context. A multi-barrier approach for source water protection is becoming the norm for managers. In addition, scenario projections should also be made for the near future (e.g. 2010-2035) and then a range of adaptive measures can be proposed.

\section{Research should present options rather than advice}

A significant issue concerns the relationship between science and policy, which is the dominant problem for the sometimes heated public debate about climate change and its impacts. To ensure the credibility and integrity of science, it is important to think about what role scientists should take on and how they should communicate results and the associated uncertainties (von Storch, 2009). What seems to be underrepresented today is a science that presents the implications of different decisions including their efficiency and costs, drawbacks and advantages (see Pielke Jr., 2007, in particular the role he describes as a "Honest Broker of Policy Alternatives"), addresses the complexity in the corresponding impact pathways and communicates the related uncertainties in a comprehensible manner. On the basis of such projections, decision makers must finally perform a comprehensive balancing of ecological, social and economic interests, with further support from scientists as necessary. This seems even conceivable for regions with poor scientific capacity if local decision-makers recognise the need for scientific support and are able to find appropriate expertise outside of the region at international level.

\section{Research must lobby for long-term monitoring}

Advancement in research is tied to long, reliable and readily accessible records that provide the basis for verifying or even improving models and process descriptions. Researchers should therefore point out the vital importance of long-term monitoring to politicians and practitioners and work towards securing funding for measuring, analysing and archiving data, with particular emphasis on high altitudes (see Sect. 4.2). Common criticisms - that monitoring is not "real science" or that most data are never used (see Lovett et al., 2007) - need to be countered with sound and purposeful consideration of parameter selection, quality control, longterm archiving, implementation in research programmes and international data exchange. It should also be clarified that long-term monitoring is essential for observing and understanding climate change. The importance of calibrating models with real-world data is critical if we hope to have confidence in the model output and transferring scientific results to water managers. Establishing data exchange networks and digitising historical data could be further steps towards an improved verification of climatic and hydrological models with a focus on mountain areas and climate change.

\subsection{Recommendations for water resources management}

\section{Management must embrace non-stationarity}

Researchers usually have limited insight into practical water resources management challenges that face professional managers, and given the diversity of watersheds it is unlikely that universally applicable recommendation can be made. Drawing attention to an increasingly uncertain future and anticipated increases in the range of variability, however, requires a new water management strategy. In our opinion, there is urgent need to break away from present stationaritybased practices which assume that natural systems fluctuate within an unchanging envelope of variability (cf. Milly et al., 2008). Considering the anticipated changes that may result from climate change, the historical record has become insufficient on its own for predicting supply and demand, even if management systems were originally designed to include risk mitigation.

\section{Management should be more adaptive at smaller scales}

More flexible management and adaptation practices can reduce the risks of failure in supply very effectively (e.g. Ajami et al., 2008), and the benefits are amplified if these practices 
are implemented into basin-wide water resources allocation and management. Adaptive management decisions should first be made at the watershed scale and community level, because that is where immediate actions are readily possible. Considering the cumulative effects, however, the next level of action needs to take place at the river basin level. This however is much more complex and time consuming.

\section{Management should embrace transboundary collaboration}

Many rivers, lakes and underground water aquifers cross national borders, and there is an increasing number of potential or already existing conflicts about water resources in a highland-lowland context at the international level (e.g. Euphrates-Tigris, Ganges-Brahmaputra, Indus, Jordan and Nile River basins), sometimes even reaching the regional level (e.g. Ebro River basin, cf. Sect. 3.1.5). The potential of sharing water resources benefits can serve as an incentive for peaceful cooperation and sustainable development (Wolf et al., 2003). Integrated water resources management at the watershed scale is now widely accepted and promoted by many international organisations. International basin management organisations such as the International Commission for the Protection of the Rhine (ICPR), the International Commission for the Protection of the Danube River (ICPDR) or the Mekong River Commission (MRC) are showing leadership in how to develop integrated basin management and adaptation programmes at multi-national basin scale. Similarly national commissions are working on basin level strategies within individual countries, as in the example of the Yellow River Conservancy Commission (YRCC) or the Changjiang Water Resources Commission (CWRC). Balancing the needs of different regions, however, presents a challenge in itself in large countries like China, and it would be of particular importance to integrate mountain regions specifically into water resources planning.

\section{Management must consider soil and vegetation conditions}

In view of the importance of soil and vegetation effects on water yield (e.g. Mark and Dickinson, 2007 for New Zealand and South Africa), land use should always be considered in water management schemes, creating Integrated Land- and Water Resources Management (cf. Falkenmark, 2009; Hoff, 2009).

\subsection{Recommendations for improving communication between research and management}

In the short term, it is unrealistic to expect water management institutions to build up appropriate infrastructure and scientific capacity to develop regional scenarios for climate change, implement sophisticated hydrological models, or develop expertise in reservoir optimisation approaches (Hamlet, 2010). Adequate scientific resources in these areas are typically available only at research institutes and universities which have, however, their own agendas and approaches and often lack the continuity required for operational purposes. This situation calls for improvements in the information flow between scientists and water managers.

\section{Researchers and managers should develop a com- mon language}

In order to improve communication between researchers and managers, a common language should be sought which circumvents ambiguities that are caused by the different professional backgrounds and the corresponding technical terms. Communicating scientific results by means of comparison with experience might also be helpful in bridging gaps, e.g. by adding that the situation observed during a recent heat wave might occur every few years in 2050 for a medium warming scenario and could even correspond to the average conditions in 2050 for a strong warming scenario (see 2003 heat wave in Europe, OcCC, 2007).

\section{Researchers and managers should establish long- term forums for interaction}

Experience has shown that successful exchange of know-how must be based on a continuous, long-term and peer-to-peer relationship between researchers and practitioners. Therefore, research institutions should actively seek a working relationship with management institutions (and vice versa) and present their research results to managers on a continuing basis. National Centres of Excellence (e.g. the Canadian Water Network or the Swiss Academy of Sciences forum for climate and global change, ProClim) are encouraged to become active participants in knowledge translation programmes. Workshops and continuing education seem to be an effective way to facilitate communication between the two parties if such events occur regularly, focus on content of mutual interest and treat both sides as equals. Permanent working groups could take on the task of organising such events.

\section{Stakeholders should be actively engaged in water resources planning}

Another interesting way of establishing successful cooperation was reported by Langsdale et al. (2007). They describe a participatory modelling exercise that was used to support the water resources community of a river basin in British Columbia in evaluating anticipated climate change impacts on a management system. A similar approach has been taken in the Columbia Basin in Canada with a programme to help mountain communities to develop a climate change adaptation strategy (Columbia Basin Trust, 2009) where interested community members, local politicians, water managers and scientist examine the vulnerability in community watersheds, prioritise the risk, and put an action strategy in place. Researchers and practitioners jointly designed an integrated model with the goal of understanding the most important and decisive components rather than aiming at a perfect 
representation of details. This kind of informal case study enables practitioners to examine management options without actual risk, to understand the specific uncertainties in and limitations of hydrological and climate models and to explore planning as a process of continuous change and adaptation instead of a stationary rule. At the same time, it enables researchers to realise the specific questions and concerns of water resources managers and shows them what kind of results are required by management practice. Involving intermediate professionals from both sides might further facilitate the building of trust and long-term relationships. Initiatives of this kind should be seized upon much more frequently, and management or political institutions should take on a proactive role in initiating them at a regional level.

\section{National initiatives are required for addressing large scale problems}

If water resources problems concern more extensive areas and are expected to take on larger dimensions, joint projects should be initiated by a national government. This crucial point will be illustrated with a number of examples of good practice from different national and international river basins below.

- For the Changjiang River, the Chinese ministry of water resources recently initiated a research project on the integrated operation of multiple reservoirs in the upper river. The project is carried out jointly by research institutes, universities and the river basin management authority, and the intermediate operation rules have turned out to be quite successful so far.

- The National Research Programme 31 on Climate Change and Natural Hazards in Switzerland, a joint project between researchers and managers, has proven very successful in examining and testing new adaptive measures to minimise the risk posed by increased extreme events.

- The EU Interreg IIIB AlpineSpace Programme requires a mix of scientific and non-scientific partners (e.g. research units; education and training centres; public authorities; local, regional and national administrations and development agencies; organisations representing enterprises; chambers of commerce and industry; public services and transport providers; agencies and NGOs) with emphasis on relevancy for practical applicability. The programme features water-related projects such as AlpWaterScarce (Water Management Strategies against Water Scarcity in the Alps) and AdaptAlp (Adaptation to Climate Change in the Alpine Space).

- The Regional Integrated Sciences and Assessments (RISA) programme was established in the United States by the National Oceanic and Atmospheric Administration (NOAA) in the mid-1990s to support research teams that focus on climate issues with relevance for decision and policy makers. The RISA programme has been very successful at conducting "place-based" research designed to address the complex relationship between climate, biogeophysical impacts, and regional management and decision making. One of the most meaningful accomplishments of the RISA programme is that it demonstrated in practical terms how to successfully link interdisciplinary scientific researchers within the university system, and how to simultaneously link these activities with long-term stakeholder relationships of a more practical nature. If done well, this results in a two-way conversation that ultimately strengthens both activities. Differences in approach and research focus from region to region, however, have led to some fairly dramatic inconsistencies in the kinds of climate change information, data, and decision support that is available in the Rockies. Therefore, more west-wide studies are needed to address these discrepancies between various studies.

- The GLOWA (Global Change and the Hydrological Cycle) programme, launched by the German Federal Ministry of Education and Research (BMBF), is an outstanding example for transdisciplinary, integrative and transboundary global change research. The programme also aims at rendering research useful for stakeholders and decision-makers, and user-friendly decision support systems were developed to integrate and transfer knowledge to more direct practical problems and applications (IHP/HWRP, 2008). Today, GLOWA features a number of cluster projects among which mountain rivers are found in Europe (Danube and Elbe Rivers), North Africa (Drâa River) and in the Middle East (Jordan River). For the Danube cluster, a comprehensive overview of research results has been compiled in an on-line global change atlas (http://www.glowa-danube. de/atlas). The Jordan River cluster is also particularly remarkable in that it brings Jordanians, Palestinians and Israelis together, using a river basin and the common concern of global change impacts as a common platform.

\subsection{Recommendations related to policy}

Water resources are inevitably embedded in a deeper political environment that allocates scarce resources. The technical act of planning for water resources thus unfolds within a set of priorities that reflect social values, themselves set by political processes. We therefore conclude our list of recommendations by addressing policy-related issues.

\section{Water resource planning requires a clear set of priorities}

In regions where the political system is not completely stable, there might be a need to implement and reinforce existing 
legislation with respect to water resources. Stronger governance systems are required to address the challenges in water resources management, and even in developed countries, capacity and funding of the responsible institutions have to be strengthened (Gurría, 2008).

\section{Water governance should promote coordination among organisations}

With view to institutional organisation, research managers have to actively lobby to find ways to remove bureaucratic obstacles, improving efficiency of organisational structures and facilitating collaboration and cooperation among different agencies as well as exchange of knowledge between research and management. There are usually many different government agencies that have the responsibility to manage water resources, and there is little collaboration and exchange between managers dealing with drinking water, wastewater, water allocations, irrigation, hydropower production etc. The first step is to streamline water agencies within governments. In Pakistan, for example, climatological measurement is primarily the responsibility of the Pakistan Meteorological Department and river flow measurement the responsibility of the Water and Power Development Authority (WAPDA). Management of the Indus Basin Irrigation System is divided between WAPDA for reservoir management and Provincial Irrigation and Drainage Departments for abstraction and distribution. Management can also become ineffective if there are many authorities involved with different objectives and agendas, or where a culture of conflict resolution is lacking. Moreover, measurement and management may be divided between several government organisations with limited or untimely data exchange and management coordination: In Peru, the hydrologic service was until recently administered by the Ministry of Defence which had little appropriate knowledge of science. This also stresses that hydrometeorological data are often seen as strategically important data that cannot be put in the public domain. Finally, unprejudiced evaluation of knowledge should be pursued to prevent political instrumentation of selected findings.

\section{Mountain research requires dedicated funding}

As regards the promotion of relevant research, additional frameworks should be established from which mountainspecific funding can be obtained. The absence of such a framework in the United States National Science Foundation is, for example, a big impediment because relevant topics in mountain water resources and climate change are spread across several divisions such as climate dynamics, hydrology, geography and spatial sciences or polar research. In order to promote the integrated assessment of regions, an overarching funding framework should be put in place for mountain research rather than providing funding agencies that focus on individual components of the earth system in mountains. The national or international research initiatives mentioned in the preceding section could complete such a funding structure with particular focus on practice-oriented research. In order to increase the autonomy and flexibility of local management institutions and provincial governments which often have a higher awareness of regional problems -, it is a good idea to provide them with funds subject to use for seeking advice from researchers or initiating cooperation with them. This would complement rather research-oriented funds and facilitate exchange of knowledge. For regions of the globe where a lack of research capacity coincides with limited funding, support is required from abroad, e.g. from cooperation and development agencies at the national level (found in many industrialised countries) or at the international level (e.g. World Bank).

\section{Academia should value applied research}

We also believe that current assessment procedures and funding strategies for academic research still tend to provide incentives that counteract practice-relevant science, although state, local, and water resources management agency supported funding does, for example, exist in the United States. Moreover, the pressure imposed on researchers by university departments to focus on high-impact publications and to constantly attract new projects complicates knowledge transfer, and researchers that focus on practice-oriented results risk being accused of not engaging in "real" science but rather in "consulting". Funding agencies need to better acknowledge and recognise dissemination of knowledge, both for researchers and for managers who are usually very constrained in their time. Interaction and exchange should not be left to the personal initiative of a few idealistic individuals but should be actively encouraged and supported.

\section{Conclusions}

At a global scale, there is currently not enough knowledge to move much beyond rather broad statements on future changes in the timing and amounts of mountain runoff, and therefore, more detailed regional studies are needed to provide water management with more reliable scenario projections. A number of research areas are relevant in this context, of which precipitation downscaling may currently have the highest prospects for improving the reliability of climate change projections in mountain areas. This is in line with the need for establishing a more integrated approach to mountain water resources research, e.g. by linking more closely hydrological and climatological research or by considering the impacts of land use changes.

In view of these challenges and uncertainties, it is imperative to support adaptation processes in water resources management institutions by disseminating research results actively through practice-relevant conduits and, more than that, to establish continuity in knowledge exchange between managers and researchers through, for example, regular 
workshops and continuing education. These adaptation processes would also benefit greatly from an ongoing effort to get water on the political agenda.

Feedback mechanisms in the climate system result in mountains being particularly vulnerable to changes in hydrology if storage in snow or ice or both is important. In addition, mountains feature high climate variability due to strong altitudinal gradients and exposure to solar radiation, frequently complicated when they represent transitional environments in terms of climate (such as the Pyrenees or the European Alps between Atlantic and Mediterranean conditions). In many mountain areas, observation networks are inadequate for capturing the heterogeneity and variability in important processes and thus strongly hinder our understanding of high-altitude regions. Overall, challenges for climate and hydrological modelling in mountain areas are clearly enhanced, which renders integrated water resources management difficult both in the mountains as well as in the lowlands, especially when several political units (states or nations) are involved.

In view of the present and future challenges in managing water resources that originate in mountain areas and the related uncertainties, there is strong need for promoting research and exchange of knowledge with practitioners. Although climate change is already a strong focus of present research strategies in developed countries, the common concerns of water resources and mountain areas are in need of more specific support at national and international level. Well-targeted programmes at international level should act to coordinate individual national actions, which would allow a certain comparability of results, facilitate the implementation and anchoring of know-how at the national level and, ideally, even foster new national initiatives. Good examples of this are recent call of the $6^{\text {th }}$ EU Framework Programme (FP)-funded CIRCLE (Climate Impact Research Coordination for a Larger Europe) on 'Climate change impacts and response options in mountainous areas' or the first call for the $7^{\text {th }}$ EU FP which funds the large-scale integrating ACQWA (Assessing Climate impacts on the Quantity and quality of Water) project under the subject 'Climate change impacts on vulnerable mountain regions'. To support implementation and practice-oriented research, national and international river commissions should also take on a more active role in promoting specific research on mountain regions in view of their importance in water resources.

\section{Supplementary material related to this article is available online at: http://www.hydrol-earth-syst-sci.net/15/471/2011/ hess-15-471-2011-supplement.pdf.}

Acknowledgements. This article is the result of the workshop "Climate Change and Mountain Water Resources Management" held in Göschenen, Switzerland, in September 2009. The workshop was sponsored by the Mountain Research Initiative (MRI) and the Swiss National Science Foundation (SNSF, project $N^{\circ}$ 20CO21127647). We would like to thank the water managers that answered our survey and provided valuable insight in problems of water management practice, as well as Yoshihide Wada, Gulnara Shalpykova, Nathan Forsythe and further colleagues for their input on specific topics. The comments of an anonymous referee, Massimiliano Zappa, Ludwig Braun and Bettina Schaefli were very helpful in improving the original manuscript. These comments and our responses (available at http://www.hydrol-earth-syst-sci-discuss net/7/2829/2010/hessd-7-2829-2010-discussion.html) may provide an additional background to reading this paper. The Global Precipitation Climatology Centre (GPCC) is acknowledged for kindly making their station catalogue available.

Edited by: B. Schaefli

\section{References}

Adam, J. C., Clark, E. A., Lettenmaier, D. P., and Wood, E. F.: Correction of global precipitation products for orographic effects, $\mathrm{J}$. Clim., 19, 15-38, 2006.

Adam, J. C., Hamlet, A. F., and Lettenmaier, D. P.: Implications of global climate change for snowmelt hydrology in the twenty-first century, Hydrol. Process., 23, 962-972, 2009.

Ajami, N. K., Hornberger, G. M., and Sunding, D. L.: Sustainable water resource management under hydrological uncertainty, Water Resour. Res., 44, W11406, doi:10.1029/2007WR006736, 2008.

Akhtar, M., Ahmad, N., and Booij, M. J.: The impact of climate change on the water resources of Hindukush-KarakorumHimalaya region under different glacier coverage scenarios, J. Hydrol., 355, 148-163, 2008.

Alford, D.: Annual runoff from glaciers in the Nepal Himalaya, http://www.mountainforum.org/oldocs/1294.pdf, last access: 18 April 2010, 2008.

Alford, D. and Armstrong, R.: The role of glaciers in stream flow from the Nepal Himalaya, The Cryosphere Discuss., 4, 469-494, doi:10.5194/tcd-4-469-2010, 2010.

Allan, J. A.: Virtual water - the water, food and trade nexus: useful concept or misleading metaphor?, Water Int., 28, 4-11, 2003.

Archer, D. R. and Fowler, H. J.: Spatial and temporal variations in precipitation in the Upper Indus Basin, global teleconnections and hydrological implications, Hydrol. Earth Syst. Sci., 8, 4761, doi:10.5194/hess-8-47-2004, 2004

Archer, D. R. and Fowler, H. J.: Using meteorological data to forecast seasonal runoff on the River Jhelum, Pakistan, J. Hydrol., 361, 10-23, 2008.

Archer, D. R., Forsythe, N., Fowler, H. J., and Shah, S. M.: Sustainability of water resources management in the Indus Basin under changing climatic and socio economic conditions, Hydrol. Earth Syst. Sci., 14, 1669-1680, doi:10.5194/hess-14-16692010, 2010.

Armstrong, R. L., Alford D., and Racoviteanu, A.: The role of glaciers in the hydrology of Nepal, in: Mountains: energy, water and food for life. The SHARE project: understanding the impacts of climate change, International Conference in Milan, Italy, 2728 May 2009, Abstracts, EvK2CNR Committee, Bergamo, Italy, 27, 2009 . 
Auer, I., Böhm, R., Jurkovic, A., Lipa, W., Orlik, A., Potzmann, R., Schöner, W., Ungersböck, M., Matulla, C., Briffa, K., Jones, P., Efthymiadis, D., Brunetti, M., Nanni, T., Maugeri, M., Mercalli, L., Mestre, O., Moisselin, J.-M., Begert, M., MüllerWestermeier, G., Kveton, V., Bochnicek, O., Stastny, P., Lapin, M., Szalai, S., Szentimrey, T., Cegnar, T., Dolinar, M., GajicCapka, M., Zaninovic, K., Majstorovic, Z., and Nieplova, E.: HISTALP - historical instrumental climatological surface time series of the Greater Alpine Region, Int. J. Climatol., 27, 17-46, 2007.

Bagla, P.: No sign yet of Himalayan meltdown, Indian report finds, Science, 326, 924-925, 2009.

Bales, R. C., Molotch, N. P., Painter, T. H., Dettinger, M. D., Rice, R., and Dozier, J.: Mountain hydrology of the western United States, Water Resour. Res., 42, W08432, doi:10.1029/2005WR004387, 2006.

Barben, M., Hänggi, P., and Viviroli, D.: Water balance in selected medium-sized catchments 1961-2007, Hydrological Atlas of Switzerland, Plate 6.5, Federal Office for the Environment, Bern, Switzerland, 2010.

Barnett, T. P., Adam, J. C., and Lettenmaier, D. P.: Potential impacts of a warming climate on water availability in snow-dominated regions, Nature, 438, 303-309, 2005.

Barnett, T. P., Pierce, D. W., Hidalgo, H. G., Bonfils, C., Santer, B. D., Das, T., Bala, G., Wood, A. W., Nozawa, T., Mirin, A. A., Cayan D. R., and Dettinger, M. D.: Human-induced changes in the hydrology of the Western United States, Science, 319, 10801083, 2008 .

Bates, B., Kundzewicz, Z. W., Wu, S., and Palutikof, J.: Climate Change and Water, IPCC Technical Paper VI of the Intergovernmental Panel on Climate Change, IPCC Secretariat, Geneva, Switzerland, 2008.

Battisti, D. S. and Naylor, R. L.: Historical warnings of future food insecurity with unprecedented seasonal heat, Science, 323, 240 244, 2009.

Bavay, M., Lehning, M., Jonas, T., and Löwe, H.: Simulations of future snow cover and discharge in Alpine headwater catchments, Hydrol. Process., 23, 95-108, 2009.

Beguería, S., López-Moreno, J. I., Lorente, A., Seeger, M., and García-Ruiz, J. M.: Assessing the effects of climate oscillations and land-use changes on streamflow in the Central Spanish Pyrenees, Ambio, 32, 283-286, 2003.

Beldring, S., Eugen-Skaugen, T., Førland, E .J., and Roald, L. A.: Climate change impacts on hydrological processes in Norway based on two methods for transferring regional climate model results to meteorological station sites, Tellus, 60A, 439-450, 2008.

Beniston, M. and Rebetez, M.: Regional behavior of minimum temperatures in Switzerland for the period 1979-1993, Theor. Appl. Climatol., 53, 231-243, 1996.

Bergström, S.: Development and Application of a Conceptual Runoff Model for Scandinavian Catchments, Bulletin Series A, No. 52, University of Lund, Sweden, 134 pp., 1976.

Betts, R. A., Boucher, O., Collins, M., Cox, P. M., Falloon, P. D., Gedney, N., Hemming, D. L., Huntingford, C., Jones, C. D., Sexton, D. M. H., and Webb, M. J.: Projected increase in continental runoff due to plant responses to increasing carbon dioxide, Nature, 448, 1037-1041, 2007.

Bezinge, A.: Grande Dixence et son hydrologie, Beschaffung hydrologischer Unterlagen in der Schweiz, Mitteilung der Lan- deshydrologie, 3, 17-51, Bern, Switzerland, 1981.

Birsan, M.-V., Molnar, P., Burlando, P., and Pfaundler, M.: Streamflow trends in Switzerland, J. Hydrol., 314, 312-329, 2005.

Bishop, M. P., Bush, A. B., Collier, E., Copland, L., Haritashya, U. K., John, S. F., Swenson, S. C., and Wahr, J.: Advancing Glaciers and Positive Mass Anomaly in the Karakoram Himalaya, Pakistan, American Geophysical Union (AGU) Fall Meeting 2008, abstract \#C32B-04, AGU, Washington DC, USA, 2008.

Böhm, R., Auer, I., Brunetti, M., Maugeri, M., Nanni, T., and Schöner, W.: Regional temperature variability in the European Alps: 1760-1998 from homogenized instrumental time series, Int. J. Climatol., 21, 1779-1801, 2001.

Bonell, M., McDonnell, J. J., Scatena, F. N., Seibert, J., Uhlenbrook, S., and Van Lanen, H. A. J.: HELPing FRIENDs in PUBs: charting a course for synergies within international water research programmes in gauged and ungauged basins, Hydrol. Process., 20, 1867-1874, 2006.

Bou-Zeid, E. and El-Fadel, M.: Climate change and water resources in Lebanon and the Middle East, J. Water Res. Pl. ASCE, 128, 343-355, 2002.

Bradley, R. S., Keimig, F. T., and Diaz, H. F.: Projected temperature changes along the American cordillera and the planned GCOS network, Geophys. Res. Lett., 31, L16210, doi:10.1029/2004GL020229, 2004.

Bradley, R. S., Vuille, M., Diaz, H. F., and Vergara, W.: Threats to water supplies in the Tropical Andes, Science, 312, 1755-1756, 2006.

Buytaert, W. and Beven, B.: Regionalisation as a learning process. Water Resour. Res., 45, W11419, doi:10.1002/hyp.7936, 2009.

Buytaert, W., Celleri, R., De Bièvre, B., Hofstede, R., Cisneros, F., Wyseure, G., and Deckers, J.: Human impact on the hydrology of the Andean páramos, Earth Sci. Rev., 79, 53-72, 2006.

Buytaert, W., Celleri, R., and Timbe, L.: Predicting climate change impacts on water resources in the tropical Andes: Effects of GCM uncertainty, Geophys. Res. Lett., 36, L07406, doi:10.1029/2008GL037048, 2009.

Buytaert, W., Vuille, M., Dewulf, A., Urrutia, R., Karmalkar, A., and Celleri, R.: Uncertainties in climate change projections and regional downscaling: implications for water resources management, Hydrol. Earth Syst. Sci., 14, 1247-1258, doi:10.5194/hess-14-1247-2010, 2010a.

Buytaert, W., Cuesta-Camacho, F., and Tobon, C.: Potential impacts of climate change on the environmental services of humid tropical alpine regions. Global Ecol. Biogeogr., doi:10.1111/j.14668238.2010.00585.x, 2010b.

Buytaert, W., Tovar, C., and Arnillas, C-A.: A regional assessment of climate change impact on water resources in the tropical Andes, in: Role of Hydrology in Managing Consequences of a Changing Global Environment, Proceedings of the BHS Third International Symposium, Newcastle, 19th-23rd July 2010, 2010c.

Casassa, G., López, P., Pouyaud, B., and Escobar, F.: Detection of changes in glacial run-off in alpine basins: examples from North America, the Alps, central Asia and the Andes, Hydrol. Process., 23, 31-41, 2009.

Cayan, D. R., Kammerdiener, S. A., Dettinger, M. D., Caprio, J. M., and Peterson, D. H.: Changes in the onset of spring in the Western United States, B. Am. Meteorol. Soc., 82, 399-415, 2001.

Chao, B. F., Wu, Y. H., and Li, Y. S.: Impact of artificial reservoir 
water impoundment on global sea level, Science, 320, 212-214, 2008.

Chen, J. and Ohmura, A.: On the influence of Alpine glaciers on runoff, in: Hydrology in Mountainous Regions I - Hydrological Measurements: The Water Cycle, IAHS Publication, 193, Wallingford, UK, 117-125, 1990.

Chen, B. D., Chao, W. C., and Liu, X. D.: Enhanced climatic warming in the Tibetan Plateau due to doubling $\mathrm{CO}_{2}$ : a model study, Clim. Dyn., 20, 401-413, 2003.

Chapagain, A. K., Hoekstra, A. Y., and Savenije, H. H. G.: Water saving through international trade of agricultural products, Hydrol. Earth Syst. Sci., 10, 455-468, doi:10.5194/hess-10-4552006, 2006.

Columbia Basin Trust: Climate Change Adaptation Resource Kit, http://cbtadaptation.squarespace.com/, last access: 29 November 2010, 2009.

Cogley, J. G., Kargel, J. S., Kaser, G., and Van der Veen, C. J.: Tracking the source of glacier misinformation, Science, 327, p. 522,2010 .

Comeau, L. E. L., Pietroniro, A., and Demuth, M. N.: Glacier contribution to the North and South Saskatchewan Rivers, Hydrol. Process., 23, 2640-2653, 2009.

Corripio, J. G., Purves, R. S., and Rivera, A.: Modeling climatechange impacts on mountain glaciers and water resources in the Central Dry Andes, in: Darkening Peaks: Glacier Retreat, Science, and Society, edited by: Orlove, B., Wiegandt, E., and Luckman, B., University of California Press, Berkeley, US, 126-135, 2007.

Coudrain, A., Francou, B., and Kundzewicz, Z. W.: Glacier shrinkage in the Andes and consequences for water resources, Hydrol. Sci. J., 50, 925-932, 2005.

Dadic, R., Corripio, J, G., and Burlando, P.: Mass-balance estimates for Haut Glacier d'Arolla, Switzerland, from 2000 to 2006 using DEMs and distributed mass-balance modelling, Ann. Glaciol., 49, 22-26, 2008.

Dai, A. and Trenberth, K. E.: Estimates of freshwater discharge from continents: latitudinal and seasonal variations, J. Hydrometeorol., 3, 660-687, 2002.

DeBeer, C. M. and Pomeroy, J. W.: Modelling snow melt and snowcover depletion in a small alpine cirque, Canadian Rocky Mountains, Hydrol. Process., 23, 2584-2599, 2009.

Déry, S. J., Stahl, K., Moore, R. D., Whitfield, P. H., Menounos, B., and Burford, J. E.: Detection of runoff timing changes in pluvial, nival, and glacial rivers of western Canada, Water Resour. Res., 45, W04426, doi:10.1029/2008WR006975, 2009a.

Déry, S. J., Stahl, K., Moore, R. D., Whitfield, P. H., Menounos, B., and Burford, J. E.: Correction to "Detection of runoff timing changes in pluvial, nival, and glacial rivers of western Canada", Water Resour. Res., 45, W06701, doi:10.1029/2009WR008244, 2009b.

Dettinger, M. D. and Cayan, D. R.: Large-scale atmospheric forcing of recent trends toward early snowmelt runoff in California, J. Clim., 8, 606-623, 1995.

DeWalle, D. R. and Rango, A.: Principles of Snow Hydrology, Cambridge University Press, Cambridge, UK, 420 pp., 2008.

Diaz, H. F. and Bradley, R. S.: Temperature variations during the last century at high elevation sites, Climatic Change, 36, 253279, 1997.

Diaz, H. F. and Eischeid, J. K.: Disappearing "alpine tundra"
Köppen climatic type in the western United States, Geophys. Res. Lett., 34, L18707, doi:10.1029/2007GL031253, 2007.

Diaz, H. F., Eischeid, J. K., Duncan, C., and Bradley, R. S.: Variability of freezing levels, melting season indicators, and snowcover for selected high-elevation and continental regions in the last 50 years, Climatic Change, 59, 33-52, 2003.

Döll, P.: Vulnerability to the impact of climate change on renewable groundwater resources: a global-scale assessment, Environ. Res. Lett., 4, 035006, doi:10.1088/1748-9326/4/3/035006, 2009.

Döll, P., Fiedler, K., and Zhang, J.: Global-scale analysis of river flow alterations due to water withdrawals and reservoirs, Hydrol. Earth Syst. Sci., 13, 2413-2432, doi:10.5194/hess-13-24132009, 2009.

Dozier, J. and Painter, T. H.: Multispectral and hyperspectral remote sensing of alpine snow properties, Annu. Rev. Earth Planet. Sci., 32, 465-494, 2004.

Dozier, J., Painter, T. H., Rittger, K., and Frew, J. E.: Time-space continuity of daily maps of fractional snow cover and albedo from MODIS, Adv. Water Resour., 31, 1515-1526, 2008.

Duan, A. and Wu, G.: Change of cloud amount and the climate warming on the Tibetan Plateau, Geophys. Res. Lett., 33, L22704, doi:10.1029/2006GL027946, 2006.

ESA (European Space Agency): coreh2o - cold regions hydrology high-resolution observatory, Report for assessment, Nordwijk, the Netherlands, 2008.

ESA (European Space Agency): SMOS: ESA's Water Mission, Nordwijk, the Netherlands, 2009.

Falkenmark, M.: Ecohydrosolidarity - towards better balancing of humans and nature, Waterfront, 2/09, 4-5, 2009.

FAO (Food and Agriculture Organization): Crops and Drops. Making the best use of water for agriculture, FAO, Rome, Italy, 28 pp., 2002.

Fekete, B. M., Vörösmarty, C. J., and Grabs, W.: High-resolution fields of global runoff combining observed river discharge and simulated water balances, Global Biogeochem. Cy., 16, 1042, doi:10.1029/1999GB001254, 2002.

Ferguson, R. I.: Snowmelt runoff models, Prog. Phys. Geog., 23, 205-227, 1999.

Finger, D., Pellicciotti, F., Konz, M., Rimkus, S., and Burlando, P.: The value of glacier mass balances, satellite snow cover images and hourly discharge on calibration of a physically based, fully distributed hydrological model, Water Resour. Res., submitted, 2011.

FOEN (Federal Office for the Environment): Hydrology Yearbook 2008, Bern, Switzerland, 623 pp., 2009.

Foppa, N., Hauser, A., Oesch, D., Wunderle, S., and Meister, R.: Validation of operational AVHRR subpixel snow retrievals over the European Alps based on ASTER data, Int. J. Rem. Sen., 28, 4841-4865. 2007.

Fountain, A. G. and Tangborn, W.: The effect of glaciers on streamflow variations, Water Resour. Res., 21, 579-586, 1985.

Fowler, H. J. and Archer, D. R.: Conflicting signals of climatic change in the Upper Indus Basin, J. Clim., 19, 4276-4293, 2006.

Fowler, H. J. and Wilby, R. L.: Beyond the downscaling comparison study, Int. J. Climatol., 27, 1543-1545, 2007.

Fowler, H. J., Blenkinsop, S., and Tebaldi, C.: Linking climate change modelling to impacts studies: recent advances in downscaling techniques for hydrological modelling, Int. J. Climatol., 27, 1547-1578, 2007. 
FSO (Federal Statistical Office): DHM100, GEOSTAT licence G158000315, Neuchâtel, Switzerland, 2003.

Fyfe, J. C. and Flato, G. M.: Enhanced climate change and its detection over the Rocky Mountains, J. Clim. 12, 230-243, 1999.

García Hernández, J., Horton, P., Tobin, C., and Boillat, J. L.: MINERVE 2010: Prévision hy-drométéorologique et gestion des crues sur le Rhône alpin, Wasser Energie Luft, 4/2009, 297-302, 2009.

Garreaud, R., Vuille, M., and Clement, A.: The climate of the Altiplano: Observed current conditions and mechanisms of past changes, Palaeogeogr. Palaeoclimatol. Palaeoecol., 194, 5-22, 2003.

GCOS (Global Climate Observing System): Global Climate Observing System. Ensuring the availability of global observations for climate, Geneva, Switzerland, 2007.

Gedney, N., Cox, P. M., Betts, R. A., Boucher, O., Huntingford, C., and Stott, P. A.: Detection of a direct carbon dioxide effect in continental river runoff records, Nature, 439, 835-838, 2006a.

Gedney, N., Cox, P. M., Betts, R. A., Boucher, O., Huntingford, C., and Stott, P. A.: Continental runoff: Gedney et al. reply, Nature, 444, E14-E15, 2006b.

Germann, U., Galli, G., Boscacci, M., and Bolliger, M.: Radar precipitation measurement in a mountainous region, Q. J. Roy. Meteor. Soc., 132, Part A, 1669-1692, 2006.

Ghassemi, F. and White, I.: Inter-basin water transfer: case studies from Australia, United States, Canada, China, and India, Cambridge University Press , New York, NY, 462 pp., 2007.

Ginot, P., Kull, C., Schwikowski, M., Schotterer, U., Pouyaud, B., and Gaeggeler, H. W.: Effects of post-depositional processes on snow composition of a subtropical glacier (Cerro Tapado, Chilean Andes), J. Geophys. Res., 106, 32375-32386, 2001.

Ginot, P., Kull, C., Schotterer, U., Schwikowski, M., and Gaeggeler, H. W.: Glacier mass balance reconstruction by sublimation induced enrichment of chemical species on Cerro Tapado (Chilean Andes), Clim. Past, 1, 169-192, 2006,

http://www.clim-past.net/1/169/2006/.

Giorgi, F., Hurrell, J. W., Marinucci, M. R., and Beniston, M.: Elevation dependency of the surface climate change signal: a model study, J. Clim., 10, 288-296, 1997.

Gleick, P. H., Cooley, H., Katz, D., Lee, E., Morrison, J., Palaniappan, M., Samulon, A., and Wolff, G. H. (Eds.): The World's Water 2006-2007: The Biennial Report on Freshwater Resources, Island Press, Washington, DC, USA, 2006.

Goodison, B. E., Louie, P. Y. T., and Yang, D.: WMO solid precipitation measurement intercomparison, final report, WMO TD 872, World Meteorological Organization, Geneva, CH, 211 pp., 1998.

GPCC (Global Precipitation Climatology Centre): Station Catalogue, Version 20.01.2010, Offenbach a. M., Germany, 2010.

GRDC (Global Runoff Data Centre): Station Catalogue, Version 13.08.2009, Koblenz, Germany, 2009.

Goderniaux, P., Brouyère, S., Fowler, H. J., Blenkinsop, S., Therrien, R., Orban, P., and Dassargues, A.: Large scale surface subsurface hydrological model to assess climate change impacts on groundwater reserves, J. Hydrol., 373, 122-138, 2009.

Gurría, A.: Water for all is a matter of good governance: the OECD perspective, Water Int., 33, 524-528, 2008.

Gurtz, J., Zappa, M., Jasper, K., Lang, H., Verbunt, M., Badoux, A., and Vitvar, T.: A comparative study in modelling runoff and its components in two mountainous catchments, Hydrol. Process., 17, 297-311, 2003.

Haeberli, W. and Beniston, M.: Climate change and its impacts on glaciers and permafrost in the Alps, Ambio, 27, 258-265, 1998.

Hagg, W. and Braun, L. N.: The Influence of Glacier Retreat on Water Yield from High Mountain Areas: Comparison of Alps and Central Asia, in: Climate and Hydrology of Mountain Areas, edited by: de Jong, C., Collins, D., and Ranzi, R., Wiley, Chichester, 263-275, 2005.

Hagg, W., Braun, L. N., Kuhn, M., and Nesgaard, T. I.: Modelling of hydrological response to climate change in glacierized Central Asian catchments, J. Hydrol., 332, 40-53, 2007.

Hall, D. K. and Riggs, G. A.: Accuracy assessment of the MODIS snow products, Hydrol. Process., 21, 1534-1547, 2007.

Hall, D. K., Riggs, G. A., Foster, J. L., and Kumar, S. V.: Development and evaluation of a cloud-gap-filled MODIS daily snowcover product, Remote Sens. Environ., 114, 496-503, 2010.

Hamlet, A. F.: Assessing water resources adaptive capacity to climate change impacts in the Pacific Northwest region of North America, Hydrol. Earth Syst. Sci. Discuss., 7, 4437-4471, doi:10.5194/hessd-7-4437-2010, 2010.

Hamlet, A. F. and Lettenmaier, D. P.: Effects of 20th century warming and climate variability on flood risk in the western U.S., Water Resour. Res., 43, W06427, doi:10.1029/2006WR005099, 2007.

Hamlet, A. F., Mote, P. W., Clark, M. P., and Lettenmaier, D. P.: Effects of temperature and precipitation variability on snowpack trends in the western United States, J. Clim., 18, 4545-4561, 2005.

Hamlet, A. F., Mote, P. W., Clark, M. P., and Lettenmaier, D. P.: Twentieth-century trends in runoff, evapotranspiration, and soil moisture in the Western United States, J. Clim., 20, 1468-1486, 2007.

Hewitt, K.: The Karakoram Anomaly? Glacier Expansion and the 'Elevation Effect,' Karakoram Himalaya, Mt. Res. Dev., 25, 332 $340,2005$.

Hingray, B., Schaefli, B., Mezghani, A., and Hamdi, Y.: Signaturebased model calibration for hydrological prediction in mesoscale Alpine catchments, Hydrol. Sci. J., 55, 1002-1016, 2010.

Hock, R.: A distributed temperature-index ice- and snowmelt model including potential direct solar radiation, J. Glaciol., 45, 101$111,1999$.

Hock, R. and Holmgren, B.: A distributed surface energy-balance model for complex topography and its application to Storglaciären, Sweden, J. Glaciol., 51, 25-36, 2005.

Hock, R., Jansson, P., and Braun, L. N.: Modelling the response of mountain glacier discharge to climate warming, in: Global Change and Mountain Regions: An Overview of Current Knowledge, edited by: Huber, U. M., Bugmann, H., and Reasoner, M., Advances in Global Change Research, 23. Springer, Dordrecht, Netherlands, 243-252, 2005.

Hoff, H.: Challenges in upland watershed management. The greenblue water approach, in: Managing Water Resources in a Time of Global Change. Mountains, Valleys and Flood Plains, edited by Garrido, A., and Dinar, A., Routledge, London, UK and New York, NY, USA, 167-189, 2009.

Hood, E., Williams, M., and Cline, D.: Sublimation from a seasonal snowpack at a continen-tal, mid-latitude alpine site, Hydrol. Process., 13, 1781-1797, 1999. 
Horton, P., Schaefli, B., Mezghani, A., Hingray, B., and Musy, A.: Assessment of climate-change impacts on alpine discharge regimes with climate model uncertainty, Hydrol. Process., 20, 2091-2109, 2006.

Houston, J.: Groundwater recharge through an alluvial fan in the Atacama desert, northern Chile: mechanisms, magnitudes and causes, Hydrol. Process., 16, 3019-3035, 2002.

Huffman, G. J., Adler, R. F., Bolvin, D. T., Giu, G., Nelkin, E. J., Bowman, K. P., Hong, Y., Stocker, E. F., and Wolff, D. B.: The TRMM Multisatellite Precipitation Analysis (TMPA): Quasiglobal, multiyear, combined-sensor precipitation estimates at fine scales, J. Hydrometeorol., 8, 38-55, 2007.

Huss, M., Farinotti, D., Bauder, A., and Funk, M.: Modelling runoff from highly glacierized alpine drainage basins in a changing climate, Hydrol. Process., 22, 3888-3902, 2008.

Huss, M., Funk, M., and Ohmura, A.: Strong Alpine glacier melt in the 1940s due to enhanced solar radiation, Geophys. Res. Lett., 36, L23501, doi:10.1029/2009GL040789, 2009.

Ibáñez, C. and Prat, N.: The environmental impact of the Spanish national hydrological plan on the lower Ebro river and delta, Water Resour. Dev., 19, 485-500, 2003.

ICOLD (International Commission on Large Dams): World Register of Dams, Paris, France, 2003.

IEA (International Energy Agency): World Energy Outlook 2006, Paris, France, 2006.

IEA (International Energy Agency): World Energy Outlook 2008, Paris, France, 2008.

IHP/HWRP (International Hydrological Programme of UNESCO / Hydrology and Water Resources Programme of WMO): GLOWA - Global change and the Hydrological Cycle, Koblenz, Germany, 71 pp., 2008.

Immerzeel, W. W., van Beek, L. P. H., and Bierkens, M. F. P.: Climate change will affect the Asian water towers, Science, 328, 1382-1385, 2010.

Inauen, N., Hiltbrunner, E., Körner, C.: Diversity responses to elevated $\mathrm{CO}_{2}$ in alpine plant communities., in: Functional Significance of Mountain Biodiversity, GMBA-DIVERSITAS Conference, 27-30 July 2010 in Chandolin, Switzerland, Abstracts, $15-16,2010$.

IPCC (Intergovernmental Panel on Climate Change): IPCC statement on the melting of Himalayan glaciers, Geneva, Switzerland, http://www.ipcc.ch/pdf/presentations/ himalaya-statement-20january2010.pdf, last access: 18 April 2010, 2010.

Jonas, T., Marty, C., and Magnusson, J.: Estimating the snow water equivalent from snow depth measurements in the Swiss Alps, J. Hydrol., 378, 161-167, 2009.

Jordan, F., Boillat, J.-L., Dubois, J., and Schleiss, A.: Real-time flood management by preventive operations on multiple alpine hydropower schemes, in: Proceedings of the $31^{\text {th }}$ IAH Congress, 11-16 September 2005 in Seoul, Korea. International Association for Hydraulic Research (IAHR), Madrid, Spain, 3235-3245, 2005.

Kaser, G., Georges, C., Juen, I., and Mölg, T.: Low-latitude glaciers: unique global climate indicators and essential contributors to regional fresh water supply. A conceptual approach, in: Global Change and Mountain Regions: An Overview of Current Knowledge, edited by: Huber, U. M., Bugmann, H., Reasoner, M. A., Springer, Dordrecht, NL, 185-196, 2005.
Kaser, G., Großhauser, M., and Marzeion, B.: Contribution potential of glaciers to water availability in different climate regimes, PNAS Early Edition, doi/10.1073/pnas.1008162107, 2010.

Kerr, Y. H., Font, J., Waldteufel, P., and Berger, M.: The Second of ESA's Opportunity Missions: The Soil Moisture and Ocean Salinity Mission - SMOS, ESA Earth Observation Quarterly, 66, 18-25, 2000.

Kondolf, G. M.: Hungry water: effects of dams and gravel mining on river channels, Env. Manag., 21, 533-551, 1998.

Köplin, N., Viviroli, D., Schädler, B., and Weingartner, R.: How does climate change affect mesoscale catchments in Switzerland?, - A framework for a comprehensive assessment, Adv. Geosci., 27, 111-119, doi:10.5194/adgeo-27-111-2010, 2010.

Knowles, N., Dettinger, M. D., and Cayan, D. R.: Trends in snowfall versus rainfall in the Western United States, J. Clim., 19, 4545-4559, 2006

Koboltschnig, G. R. and Schöner, W.: The relevance of glacier melt in the water cycle of the Alps: an example from Austria, Hydrol. Earth Syst. Sci. Discuss., 7, 2897-2913, doi:10.5194/hessd-72897-2010, 2010.

Koboltschnig, G. R., Schöner, W., Zappa, M., Kroisleitner, C., and Holzmann, H.: Runoff modelling of the glacierized alpine Upper Salzach basin (Austria): Multi-criteria result validation, Hydrol. Proc., 22, 3950-3964, 2008.

Konz, M. and Seibert, J.: On the value of glacier mass balances for hydrological model calibration, J. Hydrol., 385, 238-246, 2010.

Konz, M., Uhlenbrook, S., Braun, L. N., Shresta, A., and Demuth, S.: Implementation of a process-based catchment model in a poorly gauged, highly glacierized Himalayan headwater, Hydrol. Earth Syst. Sci., 11, 1323-1339, doi:10.5194/hess-11-13232007, 2007.

Körner, C., Morgan, J., and Norby, R.: $\mathrm{CO}_{2}$ fertilization: when, where, how much? in: Terrestrial ecosystems, in: a changing world series: Global change - The IGBP series, edited by: Canadell, J. G., Pataki, D., and Pitelka, L., Springer, Berlin, Germany, 9-21, 2007.

Koutsoyiannis, D., Montanari A., Lins H. F., and Cohn, T. A.: Discussion of 'The implications of projected climate change for freshwater resources and their management': Climate, hydrology and freshwater: towards an interactive incorporation of hydrological experience into climate research, Hydrol. Sci. J., 54, 394-405, 2009.

Kundzewicz, Z. W. and Döll, P.: Will groundwater ease freshwater stress under climate change?, Hydrol. Sci. J., 54, 665-675, 2009.

Kundzewicz, Z. W., Mata, L. J., Arnell, N. W., Döll, P., Kabat, P., Jiménez, B., Miller, K. A., Oki, T., Sen, Z., and Shiklomanov, I. A.: Freshwater resources and their management, in: Climate Change 2007: Impacts, Adaptation and Vulnerability. Contribution of Working Group II to the Fourth Assessment Report of the Intergovernmental Panel on Climate Change, edited by: Parry, M. L., Canziani, O. F., Palutikof, J. P., van der Linden, P. J., and Hanson, C. E., Cambridge University Press, Cambridge, UK, 173-210, 2007.

Kundzewicz, Z. W., Mata, L. J., Arnell, N. W., Döll, P., Jimenez, B., Miller, K., Oki, T., Sen, Z., and Shiklomanov, I. A.: The implications of projected climate change for freshwater resources and their management, Hydrol. Sci. J., 53, 3-10, 2008.

Kundzewicz, Z. W., Mata, L. J., Arnell, N. W., Döll, P., Jimenez, B., Miller, K., Oki, T., and Sen, Z.: Reply to "Climate, hydrol- 
ogy and freshwater: towards an interactive incorporation of hydrological experience into climate research": Water and climate projections, Hydrol. Sci. J., 54, 406-413, 2009.

Lambrecht, A. and Mayer, C.: Temporal variability of the nonsteady contribution from glaciers to water discharge in western Austria, J. Hydrol., 376, 353-361, 2009.

Langsdale, S., Beall, A., Carmichael, J., Cohen, S., and Forster, C.: An exploration of water resources futures under climate change using system dynamics modeling, Integr. Ass. J., 7, 51-79, 2007.

Legates, D. R. and DeLiberty, T. L.: Precipitation measurement biases in the United States, Water Resour. Bull., 29, 855-861, 1993.

Lehning, M., Völksch, I., Gustafsson, D., Nguyen, T.A., Stähli, M., and Zappa, M.: ALPINE3D: a detailed model of mountain surface processes and its application to snow hydrology, Hydrol. Process., 20, 2111-2128, 2006.

Lemke, P., Ren, J., Alley, R. B., Allison, I., Carrasco, J., Flato, G., Fujii, Y., Kaser, G., Mote, P., Thomas, R. H., and Zhang, T.: Observations: Changes in Snow, Ice and Frozen Ground, in: Climate Change 2007: The Physical Science Basis. Contribution of Working Group I to the Fourth Assessment Report of the Intergovernmental Panel on Climate Change, edited by: Solomon, S., Qin, D., Manning, M., Chen, Z., Marquis, M., Averyt, K. B., Tignor, M., and Miller H. L., Cambridge University Press, Cambridge, UK and New York, NY, USA, 337-383, 2007.

Letsinger, S. L. and Olyphant, G. A.: Distributed energy-balance modeling of snow-cover evolution and melt in rugged terrain: Tobacco Root Mountains, Montana, USA, J. Hydrol., 336, 4860, 2007.

Lettenmaier, D. P. and Burges, S. J.: Operational assessment of hydrologic models of long-term persistence, Water Resour. Res., 13, 113-124, 1977.

Leuzinger, S. and Körner, C.: Water savings in mature deciduous forest trees under elevated $\mathrm{CO}_{2}$, Glob. Change Biol. 13, 24982508, 2007.

Leuzinger, S. and Körner, C.: Rainfall distribution is the main driver of runoff under future $\mathrm{CO}_{2}$-concentration in a temperate deciduous forest, Glob. Change Biol., 16, 246-254, 2010.

Lins, H. F. and Stakhiv, E. Z.: Managing the nation's water in a changing climate, J. Am. Water Res. Assoc. 34, 1255-1264, 1998.

Liu, X. and Chen, B.: Climatic warming in the Tibetan Plateau during recent decades, Int. J. Climatol., 20, 1729-1742, 2000.

Liu, X., Cheng, Z., Yan, L., and Yin, Z.-Y.: Elevation dependency of recent and future minimum surface air temperature trends in the Tibetan Plateau and its surroundings. Global Planet. Change, 68, 164-174, 2009.

López-Moreno, J. I., García-Ruiz, J. M., and Beniston, M.: Environmental Change and water management in the Pyrenees. Facts and future perspectives for Mediterranean mountains, Global Planet. Change, 66, 300-312, 2008.

López-Moreno, I. J., Vicente-Serrano, S. M., Morán-Tejeda, E., Zabalza, J., Lorenzo-Lacruz, J., and García-Ruiz, J. M.: Impact of climate evolution and land use changes on water yield in the Ebro basin, Hydrol. Earth Syst. Sci. Discuss., 7, 2651-2681, doi:10.5194/hessd-7-2651-2010, 2010.

Lovett, G. M., Burns, D. A., Driscoll, C. T., Jenkins, J. C., Mitchell, M. J., Rustad, L., Shanley, J. B., Likens, G. E., and Haeuber, R.: Who needs environmental monitoring?, Front. Ecol. Environ., 5,
253-260, 2007.

Lundberg, A., Granlund, N., and Gustafsson, D.: Towards automated "Ground truth" snow measurements - a review of operational and new measurement methods for Sweden, Norway, and Finland, Hydrol. Process., 24, 1955-1970, 2010.

Magnusson, J., Jonas, T., López-Moreno, J. I., and Lehning, M.: Snow cover response to climate change in a high alpine and half glaciated basin in Switzerland, Hydrol. Res., 41, 230-240, 2010.

Manning, A. H. and Solomon, D. K.: An integrated environmental tracer approach to characterizing groundwater circulation in a mountain block, Water Resour. Res,, 41, W12412, doi:10.1029/2005WR004178, 2005.

Mark, A. F. and Dickinson, K. J. M.: Maximizing water yield with indigenous non-forest vegetation: a New Zealand perspective, Front. Ecol. Environ., 6, 25-34, 2007.

Mark, B. G. and Seltzer, G. O.: Tropical glacier meltwater contribution to stream discharge: a case study in the Cordillera Blanca, Peru, J. Glaciol., 165, 271-281, 2003.

Marks, D., Winstral, A., and Seyfried, M.: Simulation of terrain and forest shelter effects on patterns of snow deposition, snowmelt and runoff over a semi-arid mountain catchment, Hydrol. Process., 16, 3605-3626, 2002.

Martinec, J.: Snowmelt-runoff model for stream flow forecast, Nord. Hydrol., 6, 145-154, 1975.

Maurer, E. P., Stewart, I. T., Bonfils, C., Duffy, P. B., and Cayan, D.: Detection, attribution, and sensitivity of trends toward earlier streamflow in the Sierra Nevada, J. Geophys. Res., 112, D11118, doi:10.1029/2006JD008088, 2007.

Meek, T. H. and Meek, L. A.: Increasing inequality is already making shortages worse, Nature, 459, p. 31, 2009.

Messerli, B., Viviroli, D., and Weingartner, R.: Mountains of the world: vulnerable water towers for the 21 st century, Contribution to the Royal Colloquium on Mountain Areas: A Global Resource, AMBIO Special Report, 13, 29-34, 2004.

MeteoSwiss (Federal Office of Meteorology and Climatology): Station Catalogue for the Meteorological Gauging Network, Zürich, Switzerland, 2005.

Meybeck, M., Green, P., and Vörösmarty, C. J.: A new typology for mountains and other relief classes: An application to global continental water resources and population distribution, Mt. Res. Dev., 21, 34-45, 2001.

Michlmayr, G., Lehning, M., Koboltschnig, G., Holzmann, H., Zappa, M., Mott, R., and Schöner, W.: Application of the Alpine 3D model for glacier mass balance and glacier runoff studies at Goldbergkees, Austria, Hydrol. Process., 22, 3941-3949, 2008.

Milly, P. C. D, Betancourt, J., Falkenmark, M., Hirsch, R. M., Kundzewicz, Z. W., Lettenmaier, D. P., and Stouffer, R. J.: Stationarity is dead: whither water management?, Science, 319, 573-574, 2008.

Molden, D.: Water for Food, Water for Life: A Comprehensive Assessment of Water Management in Agriculture, Earthscan, London, UK, 624 pp., 2007.

Mölg, T., Rott, H., Kaser, G., Fischer, A., and Cullen, N. J.: Comment on "Recent glacial recession in the Rwenzori Mountains of East Africa due to rising air temperature" by Richard G. Taylor, Lucinda Mileham, Callist Tindimugaya, Abushen Majugu, Andrew Muwanga, and Bob Nakileza, Geophys. Res. Lett., 33, L20404, doi:10.1029/2006GL027254, 2006.

Molotch, N. P.: Reconstructing snow water equivalent in the Rio 
Grande headwaters using remotely sensed snow cover data and a spatially distributed snowmelt model, Hydrol. Proc., 23, 10761089, 2009.

Morris, G. L. and Fan, J.: Reservoir Sedimentation Handbook, McGraw-Hill Book Co., New York, NY, US, 848 pp., 1998.

Mote, P. W., Hamlet, A. F., Clark, M. P., and Lettenmaier, D. P.: Declining mountain snowpack in Western North America, B. Am. Meteorol. Soc., 39-49, 2005.

NASA (National Aeronautics and Space Administration): Earth Science Reference Handbook, A Guide to NASA's Earth Science Program and Earth Observing Satellite Missions, Washington D.C., USA, 2006.

Neal, J., Schumann, G., Bates, P., Buytaert, W., Matgen, P., and Pappenberger, F.: A data assimilation approach to discharge estimation from space, Hydrol. Process., 23, 3641-3649, 2009.

Neff, E. L.: How much rain does a rain gage gage?, J. Hydrol., 35, 213-220, 1977.

Nespor, V. and Sevruk, B.: Estimation of wind-induced error of rainfall gauge measurements using a numerical simulation, J. Atmos. Ocean. Tech., 16, 450-464, 1999.

New, M., Hulme, M., and Jones, P. D.: Representing twentieth century space-time climate variability. Part 1: development of a 1961-90 mean monthly terrestrial climatology, J. Clim., 12, 829-856, 1999.

Nogués-Bravo, D., Araújo, M. B., Erread, M. P., and Martínez-Rica, J. P.: Exposure of global mountain systems to climate warming during the 21st Century, Global Environ, Change, 17, 420-428, 2007.

OcCC (Organe consultatif sur les Changements Climatiques): Climate Change and Switzerland 2050. Expected Impacts on Environment, Society and Economy, Bern, Switzerland, 2007.

Oki, T. and Kanae, S.: Global hydrological cycles and world water resources, Science, 1068-1072, 2006.

ORNL (Oak Ridge National Laboratory): LandScan 2002 Global Population, Oak Ridge, TN, USA, 2002.

Parajka, J. and Blöschl, G.: Spatio-temporal combination of MODIS images potential for snow cover mapping, Water Resour. Res., 44, W03406, doi:10.1029/2007WR006204, 2008.

Parry, M. L., Canziani, O. F., Palutikof, J. P., van der Linden, P. J., and Hanson, C. E. (Eds.): Climate Change 2007: Impacts, Adaptation and Vulnerability. Contribution of Working Group II to the Fourth Assessment Report of the Intergovernmental Panel on Climate Change, Cambridge University Press, Cambridge, UK, 2007.

Peel, M. C. and McMahon, T. A.: Continental runoff: A qualitycontrolled global runoff data set, Nature, 444, E14, 2006.

Peel, M. C., Finlayson, B. L., and McMahon, T. A.: Updated world map of the Köppen-Geiger climate classification, Hydrol. Earth Syst. Sci., 11, 1633-1644, doi:10.5194/hess-11-16332007, 2007.

Pepin, N. C. and Losleben, M. L.: Climate change in the Colorado Rocky Mountains: free air versus surface temperature trends, Int. J. Climatol., 22, 311-329, 2002.

Pepin, N. C. and Lundquist, J. D.: Temperature trends at high elevations: Patterns across the globe, Geophys. Res. Lett., 35, L14701, doi:10.1029/2008GL034026, 2008.

Pepin, N. C. and Seidel, D. J.: A global comparison of surface and free-air temperatures at high elevations, J. Geophys. Res., 110, D03104, doi:10.1029/2004JD005047, 2005.
Pielke Jr., R. A.: The Honest Broker. Making Sense of Science in Policy and Politics, Cambridge University Press, Cambridge, UK, 198 pp., 2007.

Pulwarty, R. S., Jacobs, K. L., and Dole, R. M.: The hardest working river: drought and critical water problems in the Colorado River basin, in: Drought and Water Crises. Science, Technology, and Management Issues, edited by Wilhite, D. A., CRC Press, Boca Raton, FL, USA, 249-285, 2005.

Radziejewski, M. and Kundzewicz, Z. W.: Detectability of changes in hydrological records, Hydrol. Sci. J., 49, 39-51, 2004.

Rampini, A., Pepe, M., and Carrara, P.: AWARE - A tool for monitoring and forecasting Available WAter REsource in mountain environment, Final Publishable Executive Summary, Istituto per il Rilevamento Elettromagnetico dell'Ambiente, Consiglio Nazionale delle Ricerche (CNR-IREA), Milano, Italy, 45 pp., 2008.

Rees, G. and Collins, D. N.: Regional differences in response of flow in glacier-fed Himalayan rivers to climatic warming, Hydrol. Process., 20, 2157-2169, 2006.

Renard, B., Lang, M., Bois, P., Dupeyrat, A., Mestre, O., Niel, H., Sauquet, E., Prudhomme, C., Parey, S., Paquet, E., Neppel, L., and Gailhard, J.: Regional methods for trend detection: Assessing field significance and regional consistency, Water Resour. Res., 44, W08419, doi:10.1029/2007WR006268, 2008.

Regonda, S. K., Rajagopalan, B., Clark, M., and Pitlick, J.: Seasonal cycle shifts in hydroclimatology over the western united states, J. Clim., 18, 372-384, 2005.

Reusser, D. E. and Zehe, E.: Low-cost monitoring of snow height and thermal properties with inexpensive temperature sensors, Hydrol. Process., doi:10.1002/hyp.7937, 2010.

Roa García, C. E. and Brown, S.: Assessing water use and quality through youth participatory research in a rural Andean watershed. J. Environ. Manage., 90, 3040-3047, 2009.

Romanovsky, V. E., Gruber, S., Instanes, A., Jin, H., Marchenko, S. S., Smith, S. L., Trombotto, D., and Walter, K. M.: Frozen Ground, Chapter 7, In: Global Outlook for Ice and Snow, UNEP/GRID, Arendal, Norway, 181-200, 2007.

Rott, H., Cline, D., Nagler, T., Pulliainen, J., Rebhan, H., and Yueh, S.: Core- $\mathrm{H}_{2} \mathrm{O}-\mathrm{A} \mathrm{Ku}$ - and X-Band SAR Mission for Detailed Studies of Snow and Ice Processes, $7^{\text {th }}$ European Conference on Synthetic Aperture Radar, EUSAR, 02-05 June 2008, Friedrichshafen, Germany, 2008.

Rutter, N., Essery, R., Pomeroy, J., Altimir, N., Andreadis, K., Baker, I., Barr, A., Bartlett, P., Boone, A., Deng, H., Douville, H., Dutra, E., Elder, K., Ellis, C., Feng, X., Gelfan, A., Goodbody, A., Gusev, Y., Gustafsson, D., Hellström, R., Hirabayashi, Y., Hirota, T., Jonas, T., Koren, V., Kuragina, A., Lettenmaier, D., Li, W.-P., Luce, C., Martin, E., Nasonova, O., Pumpanen, J., Pyles, R. D., Samuelsson, P., Sandells, M., Schädler, G., Shmakin, A., Smirnova, T., G.; Stähli, M., Stöckli, R., Strasser, U., Su, H., Suzuki, K., Takata, K., Tanaka, K., Thompson, E., Vesala, T., Viterbo, P., Wiltshire, A., Xia, K., Xue, Y., and Yamazaki, T.: Evaluation of forest snow processes models (SnowMIP2), J. Geophys. Res., 114, D06111, doi:10.1029/2008JD011063, 2009.

Schaefli, B., Hingray, B., Niggli, M., and Musy, A.: A conceptual glacio-hydrological model for high mountainous catchments, Hydrol. Earth Syst. Sci., 9, 95-109, doi:10.5194/hess-995-2005, 2005.

Schiermeier, Q.: Glacier estimate is on thin ice, Nature, 463, 276- 
277,2010

Schmidli, J., Frei, C., and Schär, C.: Reconstruction of mesoscale precipitation fields from sparse observations in complex terrain, J. Clim., 14, 3289-3306, 2001.

Schmocker-Fackel, P., Naef, F., and Scherrer, S.: Identifying runoff processes on the plot and catchment scale, Hydrol. Earth Syst. Sci., 11, 891-906, doi:10.5194/hess-11-891-2007, 2007.

Schneeberger, C., Blatter, H., Abe-Ouchi, A., and Wild, M.: Modelling changes in the mass balance of glaciers of the northern hemisphere for a transient $2 \times \mathrm{CO}_{2}$ scenario, J. Hydrol., 282, 145-163, 2003.

Schulz, O. and de Jong, C.: Snowmelt and sublimation: field experiments and modelling in the High Atlas Mountains of Morocco, Hydrol. Earth Syst. Sci., 8, 1076-1089, doi:10.5194/hess8-1076-2004, 2004.

Seibert, J. and Beven, K. J.: Gauging the ungauged basin: how many discharge measurements are needed?, Hydrol. Earth Syst. Sci., 13, 883-892, doi:10.5194/hess-13-883-2009, 2009.

Sevruk, B.: Regional dependency of precipitation-altitude relationships in the Swiss Alps, Climatic Change, 36, 355-369, 1997.

Sevruk, B., Matokova-Sadlonova, K., and Toskano, L.: Topography effects on small-scale precipitation variability in the Swiss pre-Alps, in: Hydrology, Water Resources and Ecology in Headwaters, IAHS Publication, 248, Wallingford, UK, 51-58, 1998.

Shrestha, A. B., Wake, C. P., Mayewski, P. A., and Dibb, J. E.: Maximum temperature trends in the Himalaya and its vicinity: an analysis based, on temperature records from Nepal for the period 1971-94, J. Clim., 12, 2775-2786, 1999.

Sicart, J. E., Wagnon, P., and Ribstein, P.: Atmospheric controls of the heat balance of Zongo Glacier ( $16^{\circ} \mathrm{S}$, Bolivia), J. Geophys. Res., 110, D12106, doi:10.1029/2004JD005732, 2005.

Singh, P. and Bengtsson, L.: Impact of warmer climate on melt and evaporation for the rainfed, snowfed and glacierfed basins in the Himalayan region. J. Hydrol., 300, 140-154, 2005.

Singh, P. and Jain, S. K.: Modelling of streamflow and its components for a large Himalayan basin with predominant snowmelt yields, Hydrol. Sci. J., 48, 257-276, 2003.

Sivapalan, M., Takeuchi, K., Franks, S., Gupta, V. K., Karambiri, H., Lakshmi, V., Liang, X., McDonnell, J., Mendiondo, E., O'Connell, E. P., Oki, T., Pomeroy, J. W., Schertzer, D., Uhlenbrook, S., and Zehe, E.: IAHS decade on predictions in ungauged basins (PUB), 2003-2012: Shaping an exciting future for the hydrologic sciences, Hydrol. Sci. J., 48, 857-880, 2003.

Skaugen, T.: Modelling the spatial variability of snow water equivalent at the catchment scale, Hydrol. Earth Syst. Sci., 11, 15431550, doi:10.5194/hess-11-1543-2007, 2007.

Snyder, M., Bell, J. L., and Sloan, L. C.: Climate responses to a doubling of atmospheric carbon dioxide for a climatically vulnerable region, Geophys. Res. Lett. 29, 1514, doi:10.1029/2001GL014431, 2002.

Solomon, S., Qin, D., Manning, M., Chen, Z., Marquis, M., Averyt, K. B., Tignor, M., and Miller, H. L. (Eds.): Climate Change 2007: The Physical Science Basis. Contribution of Working Group I to the Fourth Assessment Report of the Intergovernmental Panel on Climate Change, Cambridge University Press, Cambridge, UK and New York, NY, USA, 2007.

Stahl, K., Moore, R. D., Shea, J. M., Hutchinson, D., and Cannon, A. J.: Coupled modelling of glacier and streamflow response to future climate scenarios, Water Resour. Res., 44, W02422,
doi:10.1029/2007WR005956, 2007.

Stern, N.: The Economics of Climate Change (The Stern Review), Cambridge University Press, Cambridge, UK, 2007.

Stewart, I. T., Cayan, D. R., and Dettinger, M. D.: Changes toward Earlier Streamflow Timing across Western North America, J. Clim., 18, 1136-1155, 2005.

Stewart, I. T.: Changes in snowpack and snowmelt runoff for key mountain regions, Hydrol. Proc., 23, 78-94, 2009.

Stocker, R., Leadley, P. W., and Körner, C.: Carbon and water fluxes in a calcareous grassland under elevated $\mathrm{CO}_{2}$, Funct. Ecol., 11, 222-230, 1997.

Sultana, H., Ali, N., Iqbal, M. M., and Khan, A. M.: Vulnerability and adaptability of wheat production in different climatic zones of Pakistan under climate change scenarios, Climatic Change, 94, 123-142, 2009.

Tartari, G., Vuillermoz, E., Manfredi, E., and Toffolon, R.: CEOP High Elevations initiative, GEWEX news, 19(3), 4-5, 2009.

Tenthorey, G.: Perennial névés and the hydrology of rock glaciers, Permafrost Periglac., 3, 247-252, 1992.

UNEP (United Nations Environment Programme): GEO Data Portal, http://geodata.grid.unep.ch, 2003.

Urrutia, R. and Vuille, M.: Climate Change projections for the tropical Andes using a regional climate model: Temperature and precipitation simulations for the end of the $21^{\text {st }}$ century, J. Geophys. Res., 114, D02108, doi:10.1029/2008JD011021, 2009.

USGS (United States Geological Survey): GTOPO 30 - Global 30 Arc Second Elevation Data Set, available online at http://eros.usgs.gov/\#/Find_Data/Products_and_Data_Available/ gtopo30_info, 1996.

Vano, J. A., Scott, M., Voisin, N., Stöckle, C., Hamlet, A. F., Mickelson, K. E. B., Elsner, M. M., and Lettenmaier, D. P.: Climate change impacts on water management and irrigated agriculture in the Yakima River basin, Washington, USA, Climatic Change, 2010.

Verbunt, M., Gurtz, J., Jasper, K., Lang, H., Warmerdam, P., and Zappa, M.: The hydrological role of snow and glaciers in alpine river basins and their distributed modeling, J. Hydrol., 282, 3655, 2003.

Viviroli, D. and Weingartner, R.: The hydrological significance of mountains - from regional to global scale, Hydrol. Earth Syst. Sci., 8, 1016-1029, doi:10.5194/hess-8-1017-2004, 2004.

Viviroli, D., Weingartner, R., and Messerli, B.: Assessing the hydrological significance of the world's mountains, Mt. Res. Dev., 23, 32-40, 2003.

Viviroli, D., Dürr, H. H., Messerli, B., Meybeck, M., and Weingartner, R.: Mountains of the world - water towers for humanity: typology, mapping and global significance, Water Resour. Res., 43, W07447, doi:10.1029/2006WR005653, 2007.

Voinov, A. and Bousquet, F. Modelling with stakeholders. Environ. Modell. Softw., doi:10.1016/j.envsoft.2010.03.007, in press, 2010.

von Storch, H.: Climate research and policy advice: scientific and cultural constructions of knowledge, Environ. Sci. Policy, 12, 741-747, 2009.

Vörösmarty, C. J. and Sahagian, D.: Anthropogenic disturbance of the terrestrial water cycle, Bioscience, 50, 753-765, 2000.

Vörösmarty, C. J., Green, P. A., Salisbury, J., and Lammers, R. B.: Global Water Resources: Vulnerability from Climate Change and Population Growth, Science 289, 284-288, 2000. 
Vuille, M. and Bradley, R. S.: Mean annual temperature trends and their vertical structure in the tropical Andes, Geophys. Res. Lett., 27, 3885-3888, 2000.

Vuille, M. and Milana, J. P.: High-latitude forcing of regional aridification along the subtropical west coast of South America, Geophys. Res. Lett., 34, L23703, doi:10.1029/2007GL031899, 2007.

Vuille, M., Francou, B., Wagnon, P., Juen, I., Kaser, G., Mark, B. G., and Bradley, R. S.: Climate change and tropical Andean glaciers: Past, present and future, Earth Sci. Rev., 89, 79-96, 2008.

Wada, Y., van Beek, L. P. H., Viviroli, D., Dürr, H. H., Weingartner, R., and Bierkens, M. F. P.: Global monthly water stress: II. Water demand and severity of water stress, Water Resour. Res., submitted, 2011

Wagnon, P., Ribstein, P., Francou, B., and Pouyaud, B.: Annual cycle of energy balance of Zongo glacier, Cordillera Real, Bolivia, J. Geophys. Res., 104(D4), 3907-3923, 1999a.

Wagnon, P., Ribstein, P., Kaser, G., and Berton, P.: Energy balance and runoff seasonality of a Bolivian glacier, Global Planet. Change, 22, 49-58, 1999b.

Wagnon, P., Ribstein, P., Francou, B., and Sicart, J. E.: Anomalous heat and mass budget of Glaciar Zongo, Bolivia, during the 1997-98 El Niño year. J. Glaciol., 47, 21-28, 2001.

Weber, M., Braun, L. N., Mauser, W., and Prasch, M.: Die Bedeutung der Gletscherschmelze für den Abfluss der Donau gegenwärtig und in der Zukunft, Mitt. hydrogr. Dienst Österr., $1-29,2009$.

Weingartner, R. and Aschwanden, H.: Discharge regime - the basis for the estimation of average flows, Hydrological Atlas of Switzerland, Plate 5.2, Federal Office for the Environment, Bern, Switzerland, 1992.

Weingartner, R. and Pearson, C.P.: A comparison of the hydrology of the Swiss Alps and the Southern Alps of New Zealand, Mt. Res. Dev., 21, 370-381, 2001.

Weiss, D. J. and Walsh, S. J.: Remote sensing of mountain environments, Geography Compass, 3, 1-21, 2009.

WGMS (World Glacier Monitoring Service): Glacier Mass Balance Bulletin No. 10 (2006-2007), Zürich, Switzerland, 96 pp., 2009.

Whitely Binder, L. C., Krencicki Barcelos, J., Booth, D. B., Darzen, M., Elsner, M. M., Fenske, R. A., Graham, T. F., Hamlet, A. F., Hodges-Howell, J., Jackson, J. E., Karr, C., Keys, P. W., Littell, J. S., Mantua, N. J., Marlow, J., McKenzie, D., Robinson-Dorn, M., Rosenberg, E. A., Stöckle, C., and Vano, J. A.: Preparing for climate change in Washington State, Climatic Change, in press, doi:10.1007/s 10584-010-9850-5, 2010.

Widén-Nilsson, E., Gong, L., Halldin, S., and Xu, C.-Y.: Model performance and parameter behavior for varying time aggregations and evaluation criteria in the WASMOD-M global water balance model, Water Resour. Res., 45, W05418, doi:10.1029/2007WR006695, 2009.

Wilson, J. L. and Guan, H.: Mountain-block hydrology and mountain-front recharge, in: Groundwater Recharge in a Desert Environment: The Southwestern United States, edited by: Hogan, J., Phillips, F. M., and Scanlon, B., American Geophysical Union (AGU), Washington DC, USA, 113-137, 2004.

WMO (World Meteorological Organisation): Guide to Hydrological Practice - Data acquisition and processing, analysis, forecasting and other applications, fifth edition, WMO Publication 168, Geneva, Switzerland, 1994
Wolf, A. T., Yoffe, S. B., and Giordano, M.: International waters: identifying basins at risk, Water Policy, 5, 29-60, 2003.

World Bank: Pakistan Country Water Resources Assistance Strategy. Water Economy: Running Dry, Report No. 34081-PK, Washington DC, USA, 2005.

Woodhouse, C. A., Gray, S. T., and Meko, D. M.: Updated streamflow reconstructions for the Upper Colorado River Basin, Water Resour. Res., 42, W05415, doi:10.1029/2005WR004455, 2006.

WWAP (World Water Assessment Programme): The United Nations World Water Development Report 3: Water in a Changing World, UNESCO, Paris, France and Earthscan, London, UK, 2009.

Yang, D. Q., Elomaa, E., Tuominen, A., Aaltonen, B., Goodison, B., Gunther, T., Golubev, B., Sevruk, B., Madsen, H., and Milkovic, J.: Wind-induced precipitation undercatch of the Hellman gauges, Nord. Hydrol., 30, 57-80, 1999.

Yang, D., Kane, D. L., Hinzman, L., Zhang, X., Zhang, T., and Ye, H.: Siberian Lena River hydrologic regime and recent change, J. Geophys. Res., 107(D23), 4694, doi:10.1029/2002JD002542, 2002.

Yang, D., Robinson, D., Zhao, Y., Estilow, T., and Ye, B.: Streamflow response to seasonal snow cover extent changes in large Siberian watersheds, J. Geophys. Res., 108(D18), 4578, doi:10.1029/2002JD003149, 2003.

Yang, D., Zhao, Y., Armstrong, R., Robinson, D., and Brodzik, M.J.: Streamflow response to seasonal snow cover mass changes over large Siberian watersheds, J. Geophys. Res., 112, F02S22, doi:10.1029/2006JF000518, 2007.

You, Q. L., Kang, S. C., Pepin, N., and Yan, Y. P.: Relationship between trends in temperature extremes and elevation in the eastern and central Tibetan Plateau, 1961-2005, Geophys. Res. Lett., 35, L04704, doi:10.1029/2007GL032669, 2008.

Young, C. B., Nelson, B. R., Bradley, A. A., Smith, J. A., PetersLidard, C. D., Kruger, A., and Baeck, M. L.: An evaluation of NEXRAD precipitation estimates in complex terrain, J. Geophys. Res., 104, 19691-19703, 1999.

Young, G. J., Dooge, I., and Rodda, J. C.: Global Water Resource Issues, Cambridge University Press, Cambridge, UK, 1994.

Zappa, M. and Kan, C.: Extreme heat and runoff extremes in the Swiss Alps, Nat. Hazard Earth Sys., 7, 375-389, doi:10.5194/nhess-7-375-2007, 2007.

Zappa, M., Pos, F., Strasser, U., Warmerdam, P., and Gurtz, J.: Seasonal water balance of an alpine catchment as evaluated by different methods for spatially distributed snowmelt modelling, Nord. Hydrol., 34, 179-202, 2003.

Zemp, M., Roer, I., Kääb, A., Hoelzle, M., Paul, F., and Haeberli, W.: Global Glacier Changes: facts and figures, World Glacier Monitoring Service, Zürich, Switzerland, 2008.

Zemp, M., Hoelzle, M., and Haeberli, W.: Six decades of glacier mass-balance observations: a review of the worldwide monitoring network, Ann. Glaciol., 50, 101-111, 2009.

Zhang, Q.: The South-to-North Water Transfer Project of China: Environmental implications and monitoring strategy, J. Am. Water Resour. As., 45, 1238-1247, 2009.

Zhou, Y. and Tol, R. S. J.: Evaluating the costs of desalination and water transport, Water Resour. Res., 41, W03003, doi:10.1029/2004WR003749, 2005. 